\title{
Cosmopolitismo e world music no Rio de Janeiro na passagem para o século $\mathrm{XX}^{*}$
}

\author{
CRISTINA MAGALDI**
}

\author{
Tradução de RAFAEL DOS SANTOS***
}

\begin{abstract}
RESUMO: O foco deste ensaio é a circulação internacional da música enquanto uma força globalizante que permitiu a criação de uma cultura cosmopolita no início do século XX. Meu principal objetivo é oferecer ideias sobre questões ligadas a identidades cosmopolitas e à música popular em geral, e no Rio de Janeiro em particular. Mais do que apresentar o repertório popular do início do século XX em seu potencial para exibir signos de "brasilidade", mostro a emergência da música popular nessa cidade como parte de um contexto mais amplo de cultura urbana internacional. Estou mais interessada no cosmopolitismo musical emergente e nos primeiros exemplos da "world music" como modas internacionais efêmeras que podem oferecer uma alternativa às interpretações já desgastadas sobre o papel da música nas políticas identitárias do início do século XX no Brasil.
\end{abstract}

PALAVRAS-CHAVE: música popular; cosmopolitismo; Rio de Janeiro; séc. XIX e XX; música e identidade.

\section{Cosmopolitanism and World Music in Rio de Janeiro at the Turn of the Twentieth Century}

\begin{abstract}
In this essay, I focus on the international circulation of music as a globalizing force that allowed for the creation of a cosmopolitan culture in the early 1900s. My main goal is to offer insights into issues of cosmopolitan identities and popular musics in general, and in the Brazilian capital in particular. Rather than presenting early popular musics in Rio de Janeiro in their potential to display early signs of Brazilianness, I show the emergence of popular
\end{abstract}

\footnotetext{
* Tradução do artigo "Cosmopolitanism and world music in Rio de Janeiro at the turn of the twentieth century", originalmente publicado no The Musical Quarterly, v. 92, n. 3-4, p. 329-64, dez. 2009. A presente versão em português foi feita com revisão técnica da própria autora. Em 2010 o artigo recebeu o prêmio Irving Lowens da Society for American Music (EUA) pelo melhor artigo do ano em musicologia.

${ }^{*}$ Cristina Magaldi é professora adjunta na Universidade de Towson. É autora de "Music in Imperial Rio de Janeiro: European Culture in a Musical Milieu" (2004), um livro que recebeu o prêmio Robert Stevenson da Sociedade Americana de Musicologia em 2005. Suas áreas de interesse incluem música popular, música do século XIX, música latino-americana, nacionalismos e identidades musicais. Suas publicações aparecem, entre outros, nos periódicos Popular Music, Latin American Music Review e InterAmerican Music Review. A pesquisadora está completando um livro sobre música e cosmopolitismo no Rio de Janeiro ao final do século XIX. E-mail: cmagaldi@towson.edu

*** Coordenador da equipe de tradução formada por Adelcio Camilo Machado, Daniela Vieira dos Santos, Maria Beatriz Cyrino Moreira, Sheila Zagury e Thaís Lima Nicodemo. E-mail: rdsantos.piano@gmail.com 
music in the city as part of a larger context of international urban culture. I am most interested in an emergent musical cosmopolitanism and in early examples of "world music" as ephemeral international fashions that can offer an alternative to the often historicized understandings of the role of music in identity politics of early twentieth-century Brazil.

KEYWORDS: popular music; cosmopolitanism; Rio de Janeiro; 19th and 20 th centuries; music and identity.

s reformas urbanas no Rio de Janeiro no início do século XX foram centrais
ao moto "Civilização e Progresso" do novo governo republicano. De saneamento e iluminação elétrica de ruas e parques a construções de prédios neoclássicos e largas avenidas como as da Paris contemporânea, essas renovações urbanas marcaram importantes momentos tanto da afirmação política quanto da transição cultural da capital brasileira. De um lado, os projetos de urbanização esvaziavam os cofres públicos, e o bota-abaixo forçava milhares de moradores a se realojarem em áreas suburbanas de condições precárias ${ }^{1}$; de outro lado, a reforma do antigo Rio de Janeiro tinha como objetivo promover a tão necessária infraestrutura para uma cidade que havia crescido continuamente nas décadas anteriores, dobrando sua população de 1890 para quase um milhão de habitantes em 1910 (MEADE, 1997, p.43).

A nova paisagem também acabou simbolizando o sonho de uma crescente classe média ascendente (de maioria branca), na medida em que novas fachadas arquitetônicas e novos espaços públicos modificavam modas e padrões de comportamento, dando aos moradores do Rio a sensação de estar no centro de seu país. A nova capital se tornou um ícone de transformação urbana e modernidade a ser seguido pelo "resto" de um Brasil agrário, visto pela elite política e intelectual como atrasado. O projeto do prefeito Pereira Passos para revitalizar a capital brasileira também mostrava o esforço do governo em inserir o país no centro do mundo ocidental, revelando a adoção, por parte do Brasil, de ideais europeus de civilização e progresso que associavam modernização com urbanização. Tendo a Paris de Hausmman como modelo, a transformação urbana do Rio de Janeiro foi

1 Vários estudiosos abordaram as reformas urbanas do Rio de Janeiro. Conferir MEADE, 1997; NEEDELL, 1987; BENCHIMOL, 1992. 
acompanhada por cartões-postais cuidadosamente desenhados, que ajudavam a projetar novas imagens do país no cenário internacional, bem como atrair visitantes e investidores do estrangeiro ${ }^{2}$. A nova paisagem urbana permitia o ingresso da capital brasileira na Belle Époque europeia e transformava a cidade em um centro cosmopolita nas Américas (Ex.1).

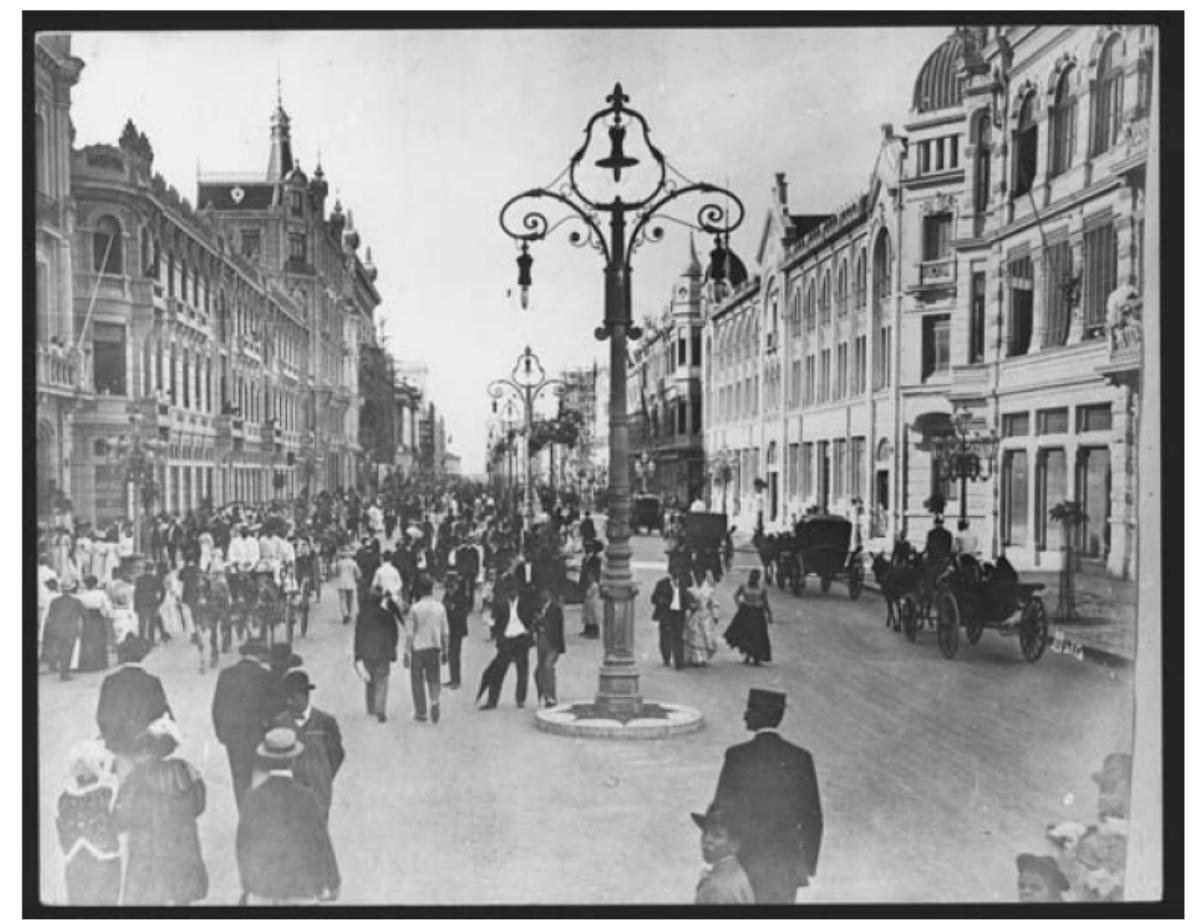

Ex. 1 - Avenida Central, Rio de Janeiro, primeira década do século XX. Foto de Augusto Malta. Fundação Museu da Imagem e do Som, Rio de Janeiro.

A nova paisagem do Rio de Janeiro era também parte de um padrão de crescimento urbano e transformação que ultrapassava a política brasileira e refletia um momento histórico internacional de transição política e social e de globalização ${ }^{3}$. De fato, além de uma nova paisagem urbana, no início do século o Rio de Janeiro compartilhava uma série de outras características com cidades emergentes na Europa e nas Américas, como: (1) a cidade abrigava um grande número de imigrantes; (2) ela garantia um espaço para a introdução de novas tecnologias e se tornava um chamariz para visitantes e investidores estrangeiros; (3) a cidade assistia a um crescimento sem precedentes de sua população, uma diversificação de seu tecido étnico e de suas expressões culturais, e

\footnotetext{
${ }^{2}$ Sobre os novos cartões-postais do Rio de Janeiro, conferir OLIVEIRA, 2007, p. 93; e LIMA, 2000, p. 97.

${ }^{3}$ Sobre as transformações no Rio de Janeiro e em outras capitais da América Latina durante o mesmo período, ver ALMANDOZ, 2002; para uma comparação entre as transformações urbanas no Rio de Janeiro e em Buenos Aires, ver NEEDELL, 1995, p.519-40.

MAGALDI, Cristina. Cosmopolitismo e world music no Rio de Janeiro na passagem para o século XX. Música Popular em Revista, Campinas, ano 1, v. 2, p. 42-85, jan.-jun. 2013.
} 
o empoderamento de uma crescente classe média. Cidades na Europa e nas Américas se conectavam também através de um conjunto de imagens compartilhadas, uma vez que tecnologias emergentes em fotografia e no cinema faziam com que ideias, ideologias e modas da Europa Ocidental viajassem mais rapidamente e para mais longe. Além disso, enquanto o crescimento e disseminação de uma economia capitalista abriam novos mercados para bens culturais em cidades do mundo todo, eles também colocavam em marcha um tecido cultural cosmopolita de alcance sem precedentes - uma cultura globalizada precoce que antecipa nossa própria época.

Mesmo que a ideia de globalização fosse assustadora, esse precoce sentido de conexão global se tornou uma parte essencial de uma nova cultura urbana no Rio de Janeiro4. Escritores locais deixaram numerosos relatos sobre a sensação de "ser parte do mundo". Olavo Bilac contava a seus leitores em 1907, por exemplo, que enquanto caminhava de um bairro a outro do Rio de Janeiro, bem como de um cinema a outro, ele conseguia fácil e rapidamente viajar também "para Paris, Roma, Nova Iorque e Milão" (apud CONDE, 2005, p.69)5. Bilac e seus contemporâneos mostravam-se também perplexos diante dos novos sons da agitada e moderna cidade e frequentemente descreviam a paisagem sonora do Rio de Janeiro destacando o barulho dos carros e dos bondes elétricos, os cliques rítmicos das máquinas de escrever, e os sons papagueados dos gramofones. Embora raramente estudada de maneira sistemática, a música popular desempenhava um papel central no fortalecimento dessa conexão cultural entre cidades emergentes e na modelagem da nova cultura urbana da capital brasileira.

A circulação internacional de música conduzida pelo crescimento do negócio de publicações musicais, pela aliança entre a música e a indústria do entretenimento nas áreas urbanas, e pela introdução de novas tecnologias como o cinema e o gramofone, permitiu uma troca inédita de repertórios e práticas musicais entre a classe média emergente do Rio de Janeiro e de cidades contemporâneas nas Américas e na Europa. Essa experiência temporal-sonora intensificou as conexões globais impulsionadas pelas grandes avenidas, fachadas arquitetônicas, imagens fotográficas e pelos primeiros filmes.

\footnotetext{
${ }^{4}$ Marite Conde explora esse aspecto da cultura carioca através das crônicas e do papel dos filmes na descrição da cidade. Ver CONDE, 2005, p.66-8.

${ }_{5}^{5}$ Originalmente encontrado em BILAC, 1907.

MAGALDI, Cristina. Cosmopolitismo e world music no Rio de Janeiro na passagem para o século XX. Música Popular em Revista, Campinas, ano 1, v. 2, p. 42-85, jan.-jun. 2013.
} 
Se a transformação da paisagem urbana pode ser vista como um exemplo tangível da tentativa do governo republicano de conectar o Rio de Janeiro com um circuito internacional de cultura cosmopolita, então um "estado de espírito cosmopolita"6 era também alcançado através de uma paisagem sonora - repertórios, práticas performáticas e experiências auditivas - que fomentava fortes ligações entre habitantes da capital brasileira e aqueles de outras cidades contemporâneas.

O foco deste ensaio é a circulação internacional da música enquanto uma força globalizante que permitiu a criação de uma cultura cosmopolita no início do século XX. Meu principal objetivo é oferecer ideias sobre questões ligadas a identidades cosmopolitas e à música popular em geral, e na capital brasileira em particular. Ao invés de explorar músicas populares do Rio de Janeiro no início do século XX em seu potencial para exibir signos de "brasilidade", mostro a emergência da música popular nessa cidade como parte de um contexto mais amplo de cultura urbana internacional. Um aspecto dessa primeira globalização da música tem aqui um significado especial: a disponibilidade, no Rio de Janeiro do início do século XX, de danças e canções de "terras distantes", um fenômeno que pode ser entendido como um estágio anterior da world music, como forma de expressão familiar no final do século XX. Essas danças e canções importadas e também produzidas localmente servem como exemplos de como a nova classe média do Rio de Janeiro imaginava a si própria e aos seus Outros. Estou mais interessada, entretanto, no cosmopolitismo musical emergente e nos primeiros exemplos de world music como modas internacionais efêmeras que podem oferecer uma alternativa às interpretações já desgastadas sobre o papel da música nas políticas identitárias do início do século XX no Brasil. Observando o desenvolvimento da música popular na capital brasileira como uma consequência de um circuito internacional de produção, circulação e consumo musical, ao invés de um fenômeno meramente local, ofereço maneiras de “desessencializar" a história da música popular brasileira e rever pressupostos gerais sobre raça, nacionalismo e identidade musical na primeira parte do século XX.

\footnotetext{
${ }^{6}$ Essa ideia foi desenvolvida por Camilla Fojas em relação à literatura latino-americana. Ver FOJAS, 2005, p. 13. 


\section{Globalização e música no Rio de Janeiro na passagem para o século XX}

A globalização da produção cultural, e da música em particular, tão real e predominante na passagem para o século XXI, tem recebido uma grande atenção de estudiosos em diferentes disciplinas. Alguns escritores têm sido céticos a respeito do panorama de disseminação em massa da música e vêem como resultado uma homogeneização das culturas musicais e a universalização do medíocre na medida em que a indústria da música, em áreas centrais, explora e/ou impõe indiscriminadamente músicas nos mercados do mundo todo. Outros têm abordado a ampla circulação da música como enriquecimento do fazer musical através de uma polinização artística e como uma oportunidade para o empoderamento de músicos e do público em áreas periféricas ${ }^{7}$. Enquanto a aceleração e crescente intensificação da globalização continuam a desafiar nossa compreensão das relações entre música e identidades coletivas nos níveis local, nacional ou internacional, estudiosos têm voltado suas atenções para o repertório e para as práticas musicais que cruzam fronteiras nacionais para criar vínculos transnacionais e transculturais ${ }^{8}$. Se hoje em dia os processos de distribuição e compartilhamento musical levaram a propagação do rock e do hip-hop a serem vistos como fenômenos internacionais, esses processos também têm desafiado visões essencialistas da música e de identidades coletivas fora dos centros de produção musical. Richard Middleton nos mostra que, durante os anos 1990, a globalização da música fez com que sistemas musicais grandes ou pequenos, globais ou locais, alcançassem uma "difícil, mas mutuamente vantajosa coexistência" (MIDDLETON e MANUEL, s.d.). Assim, há uma tendência nos estudos recentes em reconsiderar e (re)teorizar as relações contemporâneas entre música, nacionalismos e universalismos, ao mesmo tempo em que repensa as relações entre

\footnotetext{
7 Essas duas visões sobre a globalização e suas relações com a música popular brasileira contemporânea estão resumidas em MAGALDI, 1999. Para outras análises dos problemas encontrados por teóricos da world music nas décadas de 1980 e 1990, ver FELD, 2000, p.145-65.

8 A recente compilação de ensaios de Ignacio Corona e Alejandro L. Madrid (2008) sobre esse assunto é um bom exemplo.

MAGALDI, Cristina. Cosmopolitismo e world music no Rio de Janeiro na passagem para o século XX. Música Popular em Revista, Campinas, ano 1, v. 2, p. 42-85, jan.-jun. 2013.
} 
gênero, raça e identidade sociocultural no interior das políticas dos nacionalismos e da globalização9.

Tentativas de iluminar a globalização no passado têm sido, contudo, limitadas. Nayan Chanda observou que nossa compreensão da globalização é predominantemente a-histórica, uma vez que é demasiadamente ligada à história socioeconômica e cultural recente. Ele aponta que "a massiva integração econômica, e com ela a globalização cultural, ultrapassou amplamente nossa mentalidade global, que é ainda fundamentada em termos nacionalistas" (CHANDA, 2007, p.246, 246 e 319). No entanto, cientistas sociais nos oferecem exemplos de como a globalização e o cosmopolitismo cultural trabalharam, historicamente, de maneira simultânea com um conjunto de nacionalismos contrastantes, postulando que a própria ideia de construção nacional, dentro e fora do Estado-Nação, é interligada historicamente com a globalização (CHEAH e ROBBINS, 1998, p.8). Assim, as premissas que tecemos sobre globalização, nacionalismos e cosmopolitismos, e as articulações culturais resultantes de conexões e distanciamentos, de identidade ${ }^{10}$ e alteridade $^{11}$, precisam ser compreendidas não só dentro de limites geográficos mais fluidos, mas também através de contextos históricos.

No entanto, a dinâmica entre música e globalização ainda está para ser abordada sistematicamente a partir de uma perspectiva histórica. Musicólogos têm estudado os repertórios e as práticas da música artística europeia como modos de tornar exótico o Outro europeu, mas menos como poderosas ferramentas políticas da expansão imperialista dos países da Europa Ocidental. No campo da música popular, os estudos frequentemente retratam um mundo contemporâneo globalizado que alterou, positiva ou negativamente, um conjunto de sistemas musicais e culturais prévios que são axiomaticamente definidos como estáticos ou desprovidos de interações culturais. Como estudiosos da música popular tendem a situar seu objeto de estudo na metade e no final do século XX, nosso entendimento da música popular como uma mercadoria global é definida essencialmente por uma ausência de história: o elemento de novidade na

\footnotetext{
${ }^{9}$ Duas coleções de ensaios são particularmente úteis no exame da globalização hoje e no passado. Ver CHEAH e ROBBINS, 1998; e BRECKENRIDGE et al., 2002.

${ }^{10}$ No original, Self [N. do T.]

${ }^{11}$ No original, Otherness [N. do T.]

MAGALDI, Cristina. Cosmopolitismo e world music no Rio de Janeiro na passagem para o século XX. Música Popular em Revista, Campinas, ano 1, v. 2, p. 42-85, jan.-jun. 2013.
} 
globalização contemporânea da música é geralmente a chave principal para argumentos analíticos sobre estudos de política identitária. Essa, obviamente, é uma questão que vai além da globalização, pois as músicas populares e sua história na Europa e nas Américas têm sido abordadas como caricaturas e apresentadas como um Outro que não pode ser compreendido através das mesmas lentes usadas para avaliar sistemas musicais recentes, sendo assim excluídas das narrativas históricas atuais ${ }^{12}$. Estudos musicológicos lidando com a música popular antes da década de 1920 são, de fato, escassos, ainda que os livros como os de Juan Pablo González (GONZÁLEZ e ROLLE, 2005) e Derek Scott (2008) possam estimular outros pesquisadores a investigar essa área amplamente inexplorada. Os poucos estudos que tocam na história da globalização da música popular geraram visões essencialistas da música do passado, visões essas que validam as práticas musicais realizadas fora do centro de produção musical através de associações míticas com autenticidade local, raízes e com a cultura "pura"13. Se, conforme Veit Erlmann sugere, a dinâmica dos processos musicais globalizantes contemporâneos se alimenta de buscas universais através de exaltações de autenticidade e localidade (ERLMANN, 1996, p.476), é necessário cautela e atenção para evitar as abordagens historicistas que essencializam a singularidade, a nacionalidade e a diferença em um ciclo historicamente determinista. Consequentemente, há uma necessidade urgente em repensar a novidade do mundo musical globalizado contemporâneo, em problematizar a história da música popular e em reavaliar nosso entendimento sobre aquilo que Erlmann descreveu como "o espaço histórico entre CD, MTV, Graceland e tudo o que os precedeu" (ERLMANN, 1996, p.476).

Consciente da dimensão histórica do fenômeno da world music, Philip Bohlman estudou os "encontros do passado com músicas exteriores a nosso próprio

\footnotetext{
12 Embora milhares de cópias de danças e canções populares do século XIX e do início do século XX estejam disponíveis para estudo em bibliotecas e arquivos por toda a Europa e pelas Américas, esse repertório continua a ser visto como insignificante e sem valor. Jody Rose apontou recentemente que essa música popular do passado não é levada a sério porque as canções e danças dessa época eram apresentadas no contexto do teatro cômico, saturadas por um pastiche étnico, e vinculadas a questões de representação racial. Projetos recentes dos Estados Unidos com vistas a resgatar um enorme repertório de gravações mecânicas dessas primeiras canções e danças populares, além de catálogos de partituras, começam a melhorar essa situação (ver ROSEN, 2006). O surgimento da música popular na Europa, particularmente nos music halls na Inglaterra e nos café concerts e cabarés na França vêm sendo estudados por historiadores culturais e sociólogos, mais do que pelos próprios musicólogos.

${ }^{13}$ No original, folk [N. do T.]

MAGALDI, Cristina. Cosmopolitismo e world music no Rio de Janeiro na passagem para o século XX. Música Popular em Revista, Campinas, ano 1, v. 2, p. 42-85, jan.-jun. 2013.
} 
mundo" (BOHLMAN, 2002, p.1). Ele nos diz que na passagem para o século XX, conflitos internos entre identidade ${ }^{14}$ e alteridade na Europa e nos Estados Unidos foram encenados em feiras internacionais (Chicago, St. Louis, Paris, Viena), onde o público ia em busca de raízes para articular seus próprio contexto identitário dentro de um mundo interconectado, mas dominado por alguns poucos poderosos (BOHLMAN, 2002, p.15). O foco de Bohlman nas políticas de representação étnica na Europa tem importância crucial para a compreensão dos processos iniciais de globalização da música, foco esse que terá repercussões fora do âmbito europeu, conforme discutiremos mais adiante neste artigo. Contudo, enquanto os relatos de Bohlman sobre os encontros musicais do passado acontecem na Europa e nos Estados Unidos, portanto, a partir da perspectiva dos centros de produção musical, eles deixam as ideias de autenticidade, exotismo e raízes sem questionamento. A natureza complexa dos intercâmbios culturais fomentada em grande medida pela circulação de músicas entre a Europa e as Américas na passagem para o século XX envolvia exotismos e representações, como Bohlman apontou, mas também novas representações e novas contextualizações numa dinâmica transnacional complexa na qual "a cultura e o comércio alimentavam a ideologia imperial com a armadura dos exotismos disponíveis" (SEIGEL, 2005, p.98).

Para compreender os papéis políticos e culturais da música popular no Rio de Janeiro na passagem para o século XX, é necessário ter-se em mente que, assim como hoje em dia, as classes médias urbanas de cidades emergentes tinham mais afinidades entre si do que com as pessoas em suas próprias imediações, e que a música popular era parte de uma sociedade de consumo desde o princípio. É necessário também contemplar a possibilidade de que a globalização da música no passado, assim como hoje, permitia o encontro e o afastamento de uma miríade de práticas culturais de perto e de longe, e que isso gerou várias camadas de identidades de grupo a fluírem através das fronteiras dos países e nações. O repertório discutido em seguida, composto por danças e canções provenientes da Europa e dos Estados Unidos que se disseminaram no Rio de Janeiro por meio do comércio de partituras, em apresentações dos music-hall e nas primeiras gravações, auxilia-nos a investigar

\footnotetext{
14 No original, Self [N. do T.]

MAGALDI, Cristina. Cosmopolitismo e world music no Rio de Janeiro na passagem para o século XX. Música Popular em Revista, Campinas, ano 1, v. 2, p. 42-85, jan.-jun. 2013.
} 
historicamente o potencial da música para criar laços de identidade coletiva que vão além da nacionalidade. Porém, mais importante, este repertório nos permite postular que a música popular - peças orientadas para o mercado e disseminadas em grandes números pelas cidades e países - foi transnacional e situada como cosmopolita antes de ser usada politicamente como uma ferramenta para construir as alianças nacionais no século XX; que ela foi definida como uma experiência sonora das cidades antes de ser aproveitada por seu potencial para impor nacionalismos. E aqui o exemplo da capital brasileira republicana é de relevância particular. Como a música popular serviu como uma das mais poderosas ferramentas na construção e administração de ideologias nacionalistas no Brasil durante todo o século XX, sua brasilidade é frequentemente tida como intrínseca e natural, desprovida de agentes sociais e de história. Ao evocar a história da música popular brasileira como cosmopolita e transnacional, tento oferecer novas perspectivas para se entender o processo de construção de simbolismos musicais de brasilidade.

Deve-se deixar claro, no entanto, que cultura musical cosmopolita é um conceito abstrato não menos politizado do que a abordagem nacionalista. As culturas cosmopolitas são usualmente dirigidas por questões de poder econômico e cultural e, na maioria das vezes, permitem conexões de mão única entre o centro e a periferia não importa onde (ou quando) o centro ou a periferia está localizado. Na passagem para o século XX, estando-se em Paris, Londres, Buenos Aires, ou no Rio, a cosmópolis imaginada tinha de fato seu local específico de origem em Paris. Ao mesmo tempo, uma identidade cultural cosmopolita é de um tipo específico, criada entre indivíduos que habitam em grandes cidades que têm acesso e que compartilham uma variedade de práticas musicais que devem ser definidas mais por fatores temporais, posições sociais e linhagens geracionais do que por alianças nacionais - uma identidade que é moldada e remoldada historicamente mais por modas musicais do que por questões de identidades locais. De fato, enquanto exploro o potencial da música em ser historicamente transnacional e cosmopolita, também postulo que, antes da música popular local ser cooptada como ferramenta política na criação de alianças nacionais e nacionalistas, os comerciantes daquela época viam na música um potencial para congregar uma "comunidade de 
sentimento transnacional" (APPADURAI, 1996, p.8) que poderia ser usada como ferramenta para escapar e criticar, ao invés de construir, a localidade e a nacionalidade - conforme Jacqueline Loss, como uma ferramenta "contra o destino do local" (LOSS, 2005).

Se, conforme Scott afirma, podemos atribuir o nascimento da música popular tal qual a entendemos hoje - uma música explorada comercialmente, dirigida para o mercado e disseminada em massa - ao surgimento dos music halls, dos café concerts, cabarés e dos salões de dança nas cidades europeias em meados do século XIX, é exatamente sua origem em um contexto urbano que permitiu sua comercialização em várias cidades contemporâneas fora da Europa. Mesmo se os primeiros music halls da Inglaterra e da França tivessem conexões com as raízes camponesas do seu público, o crescimento da popularidade da música e a modelação de seus estilos estavam interligados a um contexto urbano emergente - um contexto dependente das novas, mesmo que frágeis, relações de poder e que envolviam a mistura de um grande número de pessoas de várias origens ${ }^{15}$, que se confrontavam em (re)negociações sociais, étnicas, raciais e de gênero. Portanto, não se deve ficar surpreso com o fato de que o mercado dessa incipiente música popular europeia tenha se estendido rápida e facilmente para além das suas fronteiras e que tenha encontrado terreno fértil em cidades por todas as Américas $^{16}$. O Rio de Janeiro da Primeira República foi uma dessas cidades com um mercado florescente para o que Scott chamou de o "estilo revolucionário" da música popular emergente ${ }^{17}$. Os investimentos do governo republicano na ideia da modernidade urbana, civilização e progresso, combinados com o crescimento da população urbana e os avanços tecnológicos, possibilitaram a participação dos moradores da capital brasileira no circuito internacional da música cosmopolita ${ }^{18}$. Mas a participação do Rio de Janeiro na globalização da música se iniciou quando já havia uma

\footnotetext{
${ }^{15}$ No original, backgrounds [N. do T.]

16 Sobre as trocas e apropriações de canções entre Nova Iorque, Londres e Paris nos anos de 1880, ver WHITING, 1999, p.24.

17 Scott nota que as mudanças sociais nas cidades europeias e a incorporação da música ao sistema da empresa capitalista levaram ao surgimento de um novo estilo musical e de um novo gênero em meados do século XIX. A nova "linguagem" da música popular, com diferentes dialetos e sotaques, também demandou novas convenções e rotinas musicais, bem como novas práticas performáticas. Ver SCOTT, 2008, p.3-12.

18 Sobre as conexões entre a capital brasileira e Paris durante a monarquia, ver MAGALDI, 2004.

MAGALDI, Cristina. Cosmopolitismo e world music no Rio de Janeiro na passagem para o século XX. Música Popular em Revista, Campinas, ano 1, v. 2, p. 42-85, jan.-jun. 2013.
} 
cultura musical urbana delineada e um mercado estabelecido para a música popular nas cidades europeias. O público do Rio de Janeiro se envolveu com a nova música popular depois dela já ter sido caracterizada tanto como urbana quanto como cosmopolita. Para o público e para os músicos da capital brasileira, a música popular nascia como uma música citadina já pronta, como parte essencial de uma cultura cosmopolita adaptada para preencher as necessidades daqueles que compartilhavam as delícias e frustrações da metrópole ao final do século.

\section{Cosmopolitismo musical no Rio de Janeiro da República Velha}

Embora o novo governo republicano não fosse um patrono ideal para a música de elite, a sua política permitiu o crescimento do mercado de entretenimento na capital do Brasil, um negócio que respondia primordialmente às demandas de uma classe média emergente. Empresas de entretenimento da iniciativa privada no Rio de Janeiro lutaram para alcançar as das cidades européias fazendo com que o público se sentisse como se fosse parte da cena musical globalizada. Relatando a vida noturna da cidade na passagem para o século XX, Luiz Edmundo notou que

no Rio, nós podemos nos orgulhar de possuir o mais alto número dos melhores music halls disponíveis na face da terra [...]. Aqui nós temos as companhias e os artistas que se apresentam nos mais famosos music halls na Europa e na América do Norte, como a Alhambra em Londres, o Moulin Rouge em Paris e o Winter Garden em Berlim. (EDMUNDO, 1987, p.173)

Empresários locais e imigrantes investiram pesadamente no desejo da elite intelectual do Rio de Janeiro em participar da vida boêmia urbana da Belle Époque e apostaram no sucesso de conhecidas fórmulas e práticas musicais estrangeiras que eram centrais na vida cultural da Europa urbana. Music halls e cabarets com nomes iguais aos elegantes estabelecimentos europeus como Maison Moderne, Moulin Rouge e High Life (posteriormente renomeado de Folies Bergère) somavam-se aos já cobiçados cafés concertos no Rio de janeiro, às menos refinadas casas de chope, e aos 
chopes berrantes, vistos como locais "inferiores"19. Muitos destes lugares, localizados na Rua do Lavradio e suas imediações, foram equipados para exibir filmes e incluíam um palco para apresentações de pequenas peças teatrais, de música e dança. A música era normalmente executada por um pequeno grupo de cinco ou seis músicos, e nos estabelecimentos menos luxuosos, às vezes até por três instrumentos, como a flauta, o violão e o cavaquinho. Alguns, contudo, poderiam oferecer música ao vivo com apenas um "velho piano Pleyel alugado", como relembra Edmundo, que servia também para acompanhar as chanteuses internationales ou ainda para interpretar valsas, schottisches e polcas (EDMUNDO, 1987, p.179-81).

A música nova e moderna também entretinha o público nas salas de espera construídas especificamente como teatros de cinema, como o Cine Parisiense, inaugurado em 1907 na nova Avenida Central. Na área da espaçosa sala de espera, seu dono, o italiano Rosario Staffa, podia entreter seu público com performances musicais ao vivo por um pianista, uma pequena orquestra, um gramofone, e mais tarde, em 1908, também com uma pianola elétrica (LIMA, 2000, p. 239, 259).

É difícil calcular precisamente o número de estilos musicais disponíveis aos residentes do Rio de Janeiro no começo do século XX. Um exame da lista de publicações nas capas das partituras, dos catálogos das editoras, dos anúncios das lojas musicais e nos primeiros catálogos de gravações nos dá uma ideia da importância e significação da música popular na capital brasileira na primeira república. Milhares de valsas, polcas, mazurkas e schottisches, bem como canções em francês, inglês, italiano e português, escritas por compositores locais, somavam-se às intermináveis listas de publicações estrangeiras do mesmo estilo. Um olhar mais atento a estas listas mostra que a música de compositores como Cécile Chaminade (1857-1944) e Emile Waldteufel (1837-1915), bem como os anteriores campeões do mercado internacional de música do século XIX, como a família Strauss, Oliver Métra (1830-1889), e Émile Prudent (1818-1863), eram hits incontestáveis na capital brasileira. Edmundo recorda que nos music halls do Rio de Janeiro, as chansons de Montmartre, com suas curtas e suaves melodias e, algumas vezes com pornográficas letras francesas, eram tão populares que ameaçavam retirar os antiquados cantores

\footnotetext{
19 No original, low-brow [N. do T.]

MAGALDI, Cristina. Cosmopolitismo e world music no Rio de Janeiro na passagem para o século XX. Música Popular em Revista, Campinas, ano 1, v. 2, p. 42-85, jan.-jun. 2013.
} 
líricos italianos do mercado (EDMUNDO, 1987, p 174). As canções francesas também inspiraram o fenômeno local das cançonetas. Muitos intelectuais, cronistas e escritores se aventuraram na composição de letras em português para cançonetas, e os compositores também entraram na moda, criando dúzias de melodias ${ }^{20}$, algumas das quais foram incorporadas em cenas cômicas e intermezzos teatrais.

Os intérpretes locais mantinham-se ocupados tocando estas canções e danças nas salas de espera dos teatros e dos teatros de cinema, em pequenos palcos de cafésconcertos e nos music halls; sua popularidade aumentava enquanto suas composições se espalhavam pelos os salões de dança e para as performances ao ar livre em parques, onde as famílias se socializavam. Uma imensa quantidade destas peças, disponíveis em partituras, também alcançou o domínio feminino das salas de estar privadas. E se não se podia tocar a música de Waldteufel em casa, ou ouvi-la nos music halls, era possível desfrutá-la na pianola, que oferecia os hits destes compositores por um preço modesto. A chegada do gramofone, uma máquina "moderna" e "capaz de reproduzir no Rio as vozes de cantores e da música de bandas e de intérpretes de todo o mundo", de acordo com um anúncio de jornal (JORNAL..., 5 mai. 1910, 19 mai. 1910, 1 set. 1910) abriu uma nova gama de possibilidades para se apreciar música. Juntas, estas canções e danças, importadas e locais, formavam uma espécie de ambiente sonoro que contribuiu para definir o contexto urbano do Rio de Janeiro, e permitiu que as pessoas se situassem no tempo e no espaço em uma grande e moderna cidade na passagem para o século XX (ver Ex. 2).

Foi exatamente a necessidade de suprir o crescente mercado de entretenimento do Rio de Janeiro com novas músicas que levou a uma explosão na produção musical local. Assim como os empresários locais repetiram os modelos do entretenimento do público das capitais europeias, também o fizeram os compositores e intérpretes, que rapidamente forneceram uma enorme produção direcionada ao mercado local. Deste modo, em cidades como o Rio de Janeiro, a indústria musical era alimentada simultaneamente pela música local e importada, mas estas estavam interconectadas - dos títulos das peças a suas linhas melódicas, dos padrões rítmicos de acompanhamento à linguagem utilizada nas canções, os limites de autoria, originalidade e origens eram de certa forma irrelevantes. A atualização das canções

\footnotetext{
${ }^{20}$ No original, tunes by the dozen [N. do T.]

MAGALDI, Cristina. Cosmopolitismo e world music no Rio de Janeiro na passagem para o século XX. Música Popular em Revista, Campinas, ano 1, v. 2, p. 42-85, jan.-jun. 2013.
} 
importadas com letras em português e o disfarce de melodias conhecidas através de novos títulos, dirigidas a situações familiares, faziam todos parte do jogo. Deste modo, quando em 1908 o pianista e compositor Ernesto Nazareth (1863-1934) começou a tocar suas valsas e polcas na luxuosa sala de espera do novo Cine-teatro Odeon, ele conquistou notoriedade local exatamente pela sua habilidade de oferecer à audiência suas danças - valsas, polcas, tangos, schottisches, e mazurkas - que eram extraordinariamente bem construídas mas, ao mesmo tempo, eram em um estilo que já estava na moda e cristalizado internacionalmente. Não menos que o rock no Rio de Janeiro de hoje, as composições de Nazareth eram obras transnacionais que respondiam às demandas cosmopolitas do público carioca na Primeira República.

Podemos postular, portanto, que o envolvimento com a música popular deste período permitiu um sentimento mais cosmopolita em lugares que se encontravam fora dos centros originais de produção. Se, por um lado, aqueles que forneciam as canções e danças dos music halls ingleses ou dos cafés concertos parisienses eram beneficiados pelas vendas no estrangeiro de suas músicas, eles estavam engajados primordialmente com seu próprio fazer musical local, enquanto, aqueles do Rio de Janeiro tinham à sua disposição um espectro mais amplo de produções estrangeiras. O público na capital brasileira podia desfrutar ao mesmo tempo - às vezes na mesma noite - da música dos music halls de Londres, dos salões de dança de Viena, dos cabarets de Montmartre, da música de Portugal, da Espanha e dos Estados Unidos, juntamente com a produção dos compositores locais que produziam réplicas destas músicas para o consumo local. No Rio de Janeiro o público podia ouvir música da Europa ou dos Estados Unidos, escolher dentre uma variedade de estilos, envolvendo-se com as modas de diferentes locais, ouvir e cantar sobre uma gama de questões políticas e sociais que estavam longe deles assim como aquelas que aconteciam aos arredores, participando assim de um espectro amplo da cultura cosmopolita global. Este irônico paradoxo no fluxo musical entre centro e periferia consistiu em um importante ingrediente na paisagem sonora local do Rio de Janeiro. Geograficamente distantes dos centros de produção musical, o público do Rio de Janeiro era verdadeiramente cosmopolita; para ele, o caráter de novidade e de 
"estar na moda" 21 da música eram certamente fatores importantes, mas a variedade e o ecletismo eram também vitais na cena da música popular.

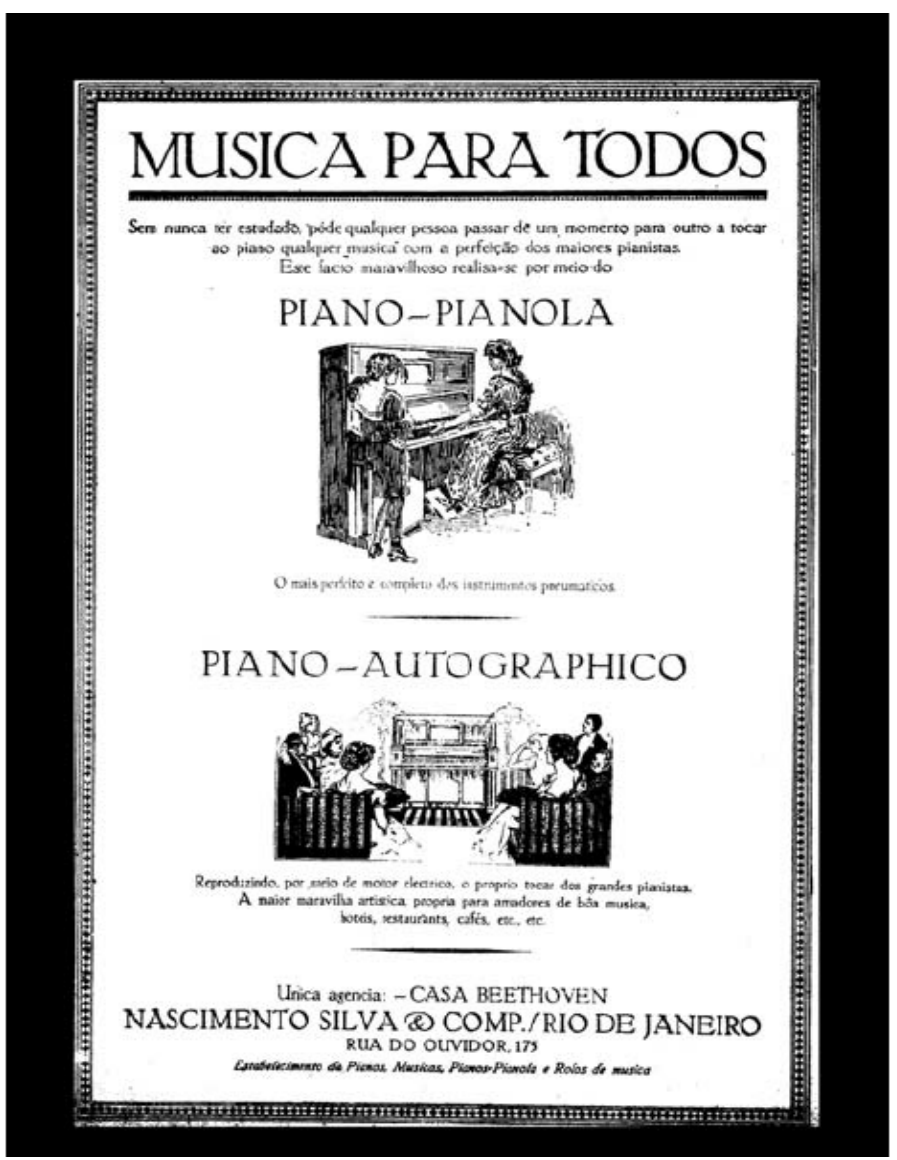

Ex. 2 - Propaganda de Nascimento Silva E Compania. Em cima: "Sem nunca ter estudado, qualquer pessoa pode passar de um momento para outro a tocar ao piano qualquer música com a perfeição dos maiores pianistas. Este facto maravilho realisa-se por meio do piano-pianola, o mais perfeito e completo dos instrumentos pneumáticos". Abaixo: "Reproduzido, por meio de motor eléctrico, o próprio tocar dos grandes pianistas. A maior maravilha artística, própria para amadores de boa música, hoteis, restaurantes, cafés, etc, etc..."

A produção do pianista e compositor Aurélio Cavalcanti (1874-1915)22 fornece um bom exemplo desta interação complexa entre cosmopolitismo e localidade. Cavalcanti era uma figura proeminente na vida noturna do Rio de Janeiro e um dos compositores e intérpretes mais populares na cidade na virada do século XX. Com sua habilidade como pianista e suas peças memoráveis, Cavalcanti aquecia

\footnotetext{
${ }^{21}$ No original, fashionable [N. do T.]

22 Embora Aurélio Cavalcanti tenha sido um compositor prolífico e uma reconhecida figura na vida noturna do Rio de Janeiro, sua biografia ainda demanda um estudo mais aprofundado. Luiz Edmundo (1987, p.174) inclui em suas memórias uma ilustração (de Calixto) de uma performance pianística de Aurélio Cavalcanti. 
os music-halls locais e preenchia as crônicas dos comentaristas, os quais o descreviam com um entusiasmo comparável a aquele associado aos pop stars do século XX. As peças de Cavalcanti eram obrigatórias nos salões privados das famílias de classe média, nos circuitos masculinos dos music halls, e nos chopes berrantes na Rua do Lavradio e arredores. Sua música cruzou fronteiras sociais e compartilhou a devoção do público local junto aos trabalhos de figuras internacionais como Waldteufel e a família Strauss. Cavalcanti foi particularmente notável pela popularidade de suas valsas e polcas que, de acordo com comentaristas da época, eram uma parte essencial da paisagem sonora da Bélle Époque do Rio de Janeiro. Referido por alguns de seus contemporâneos como o "rei das valsas", as danças de Cavalcanti mostram seu conhecimento dos estilos populares mais recentes de seu tempo. Ele escreveu centenas delas, algumas das quais revelam uma capacidade criativa difícil de ser encontrada nas composições dos mais renomados compositores do além-mar.

A música de Cavalcanti serve como exemplo de como os compositores (e por extensão, o público) fora de Paris, Londres ou Nova York almejavam se tornar cosmopolitas. Sua "Brejeira, polca francesa" (1900) nos dá uma ideia de seu estilo musical, bem como do contexto cosmopolita em que foi composta (ver Ex. 3-5).

"Bregeira" é escrita na forma usual de dança em três partes que se repetem (AABBAACCAA); cada parte é independente e, assim como a maioria das polcas contemporâneas, é construída por pares regulares de frases de oito compassos. Analisando as danças europeias da segunda metade do século dezenove, Scott mostrou que as possibilidades surgidas pela associação da música com o mercado de entretenimento em Londres, Paris e Viena iniciaram uma revolução musical em termos de prática de performance, novos estilos musicais, e novas convenções estéticas ${ }^{23}$. A "Bregeira" de Cavalcanti é um exemplo típico que demonstra que os compositores que estavam fora das capitais europeias entenderam bem e adotaram esta revolução musical. Embora a estrutura de sua polca não adicione muito às composições já estabelecidas no mesmo estilo, as linhas melódicas descendentes de "Bregeira", seguidas de saltos repentinos de até uma oitava e os finais sobre notas graves acentuadas, demonstram que Cavalcanti utilizava facilmente os motivos do "yodeling" vienense, tão comuns na música

\footnotetext{
23 SCOTT, 2008, p.3-12 (ver, em particular, a p.7).

MAGALDI, Cristina. Cosmopolitismo e world music no Rio de Janeiro na passagem para o século XX. Música Popular em Revista, Campinas, ano 1, v. 2, p. 42-85, jan.-jun. 2013.
} 
de Strauss e nas danças parisienses de Waldteufel. Cavalcanti também fez amplo uso do ritmo característico da polca na melodia, uma combinação de semínima, colcheia e duas semicolcheias, para contrastar com o firme "oom-pah", figura rítmica da marcha no baixo, e para criar o "swing" vivo realizado na performance. A polca de Cavalcanti também revela que ele estava ciente das novidades harmônicas que Strauss havia estabelecido em suas danças, utilizando a sexta acrescentada na melodia no segundo compasso para criar interesse melódico e contrastar com o movimento previsível de Si bemol para Mi bemol, e Fá. Em suma, "Bregeira” mostra Cavalcanti como um compositor de polcas em plena forma, preenchendo perfeitamente as expectativas dos dançarinos e ouvintes acostumados com o estilo utilizado pelos compositores europeus contemporâneos. "Bregeira" é uma polca "francesa", designação dada pelo próprio Cavalcanti, que estava ciente também das distinções de andamento nas performances das polcas em cidades diferentes; "francesa" aqui significa que "Bregeira" deveria ser uma dança de movimento vivo, mas interpretada em um tempo mais lento.

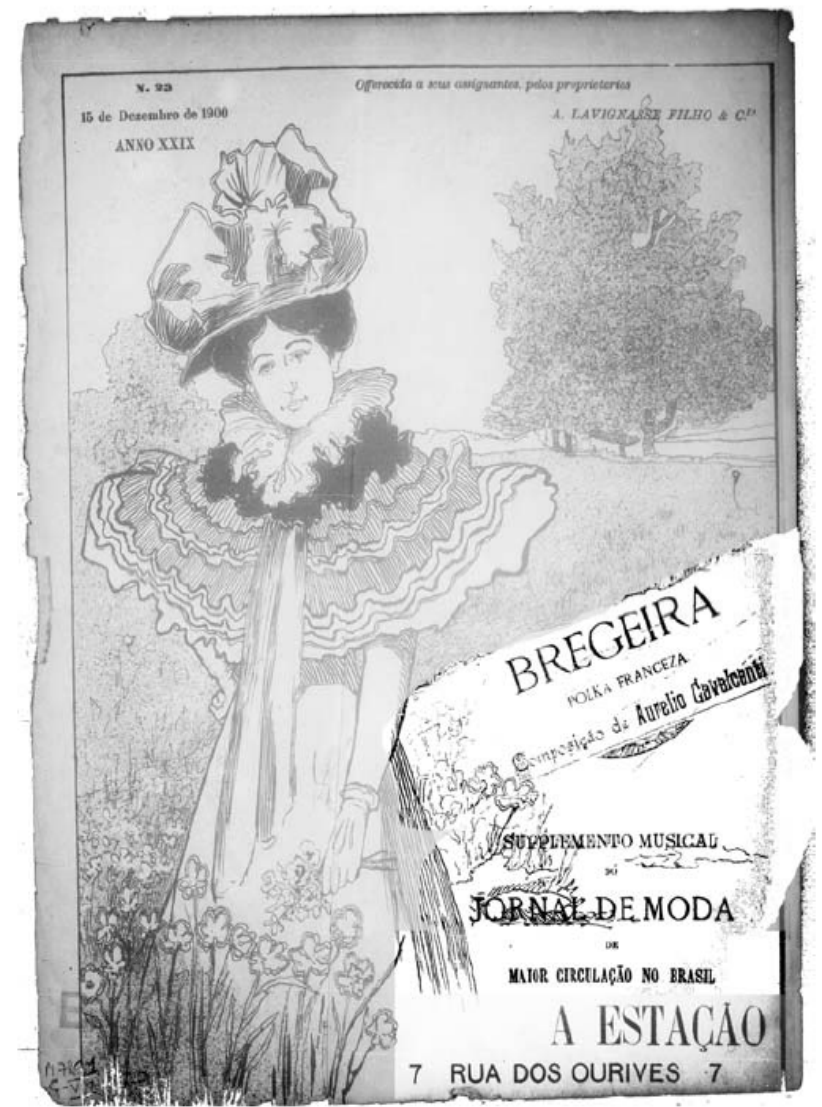

Ex. 3 - Capa da partitura de "Bregeira", de Aurélio Cavalcanti, polka francesa. Biblioteca Nacional do Rio de Janeiro, Divisão de Música e Arquivo Sonoro. 

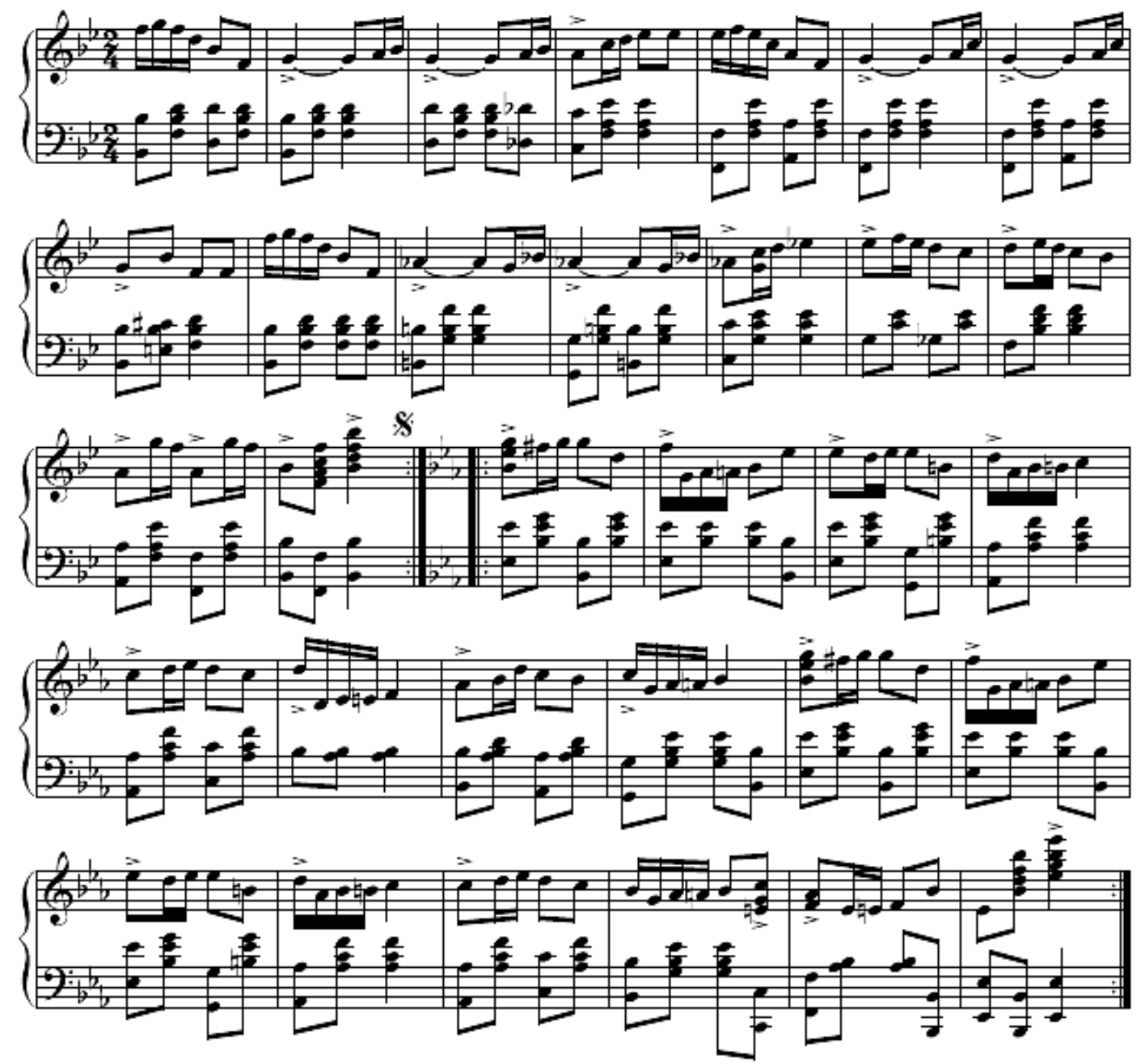

Ex. 4 - Aurélio Cavalcanti, "Bregeira", polka francesa (1901) (Rio de Janeiro: A. Lavignasse Fillho E Cia.). Biblioteca Nacional do Rio de Janeiro, Divisão de Música e Arquivo Sonoro.
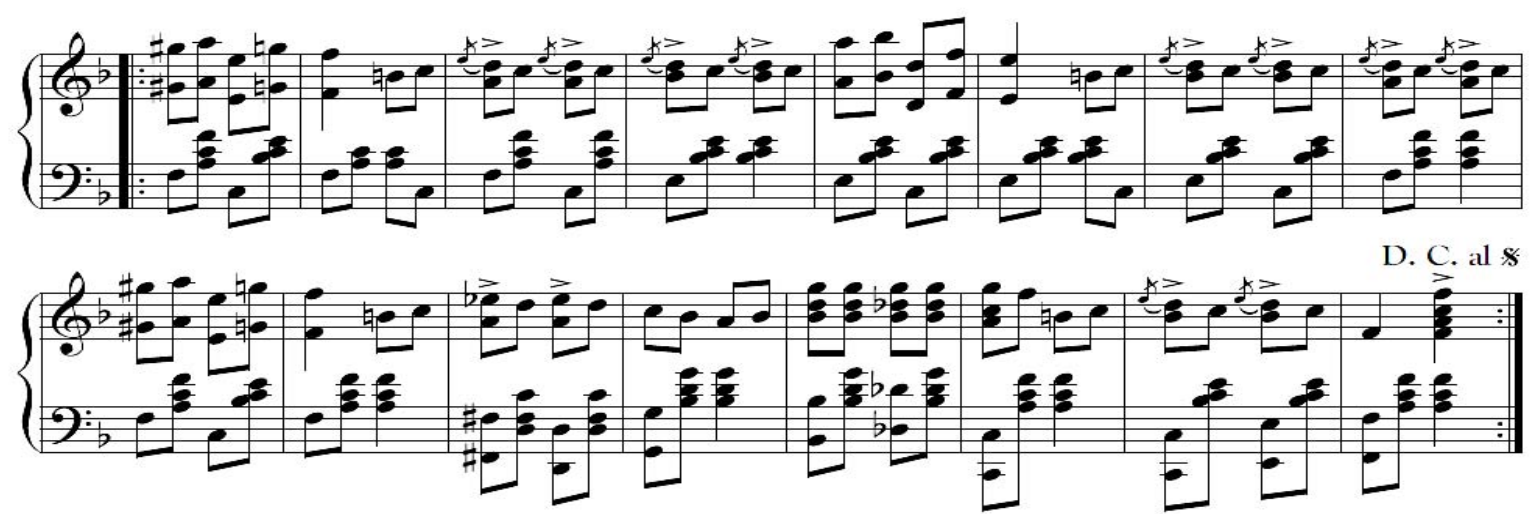

Ex. 5 - Aurélio Cavalcanti, "Bregeira", polka francesa (1901) (Rio de Janeiro: A. Lavignasse Fillho \& Cia.). Biblioteca Nacional do Rio de Janeiro, Divisão de Música e Arquivo Sonoro.

A valsa de Cavalcanti "Buenos dias, valsa espanhola" oferece outra faceta do cosmopolitismo deste versátil compositor brasileiro (ver Ex. 6-8).

MAGALDI, Cristina. Cosmopolitismo e world music no Rio de Janeiro na passagem para o século XX. Música Popular em Revista, Campinas, ano 1, v. 2, p. 42-85, jan.-jun. 2013. 


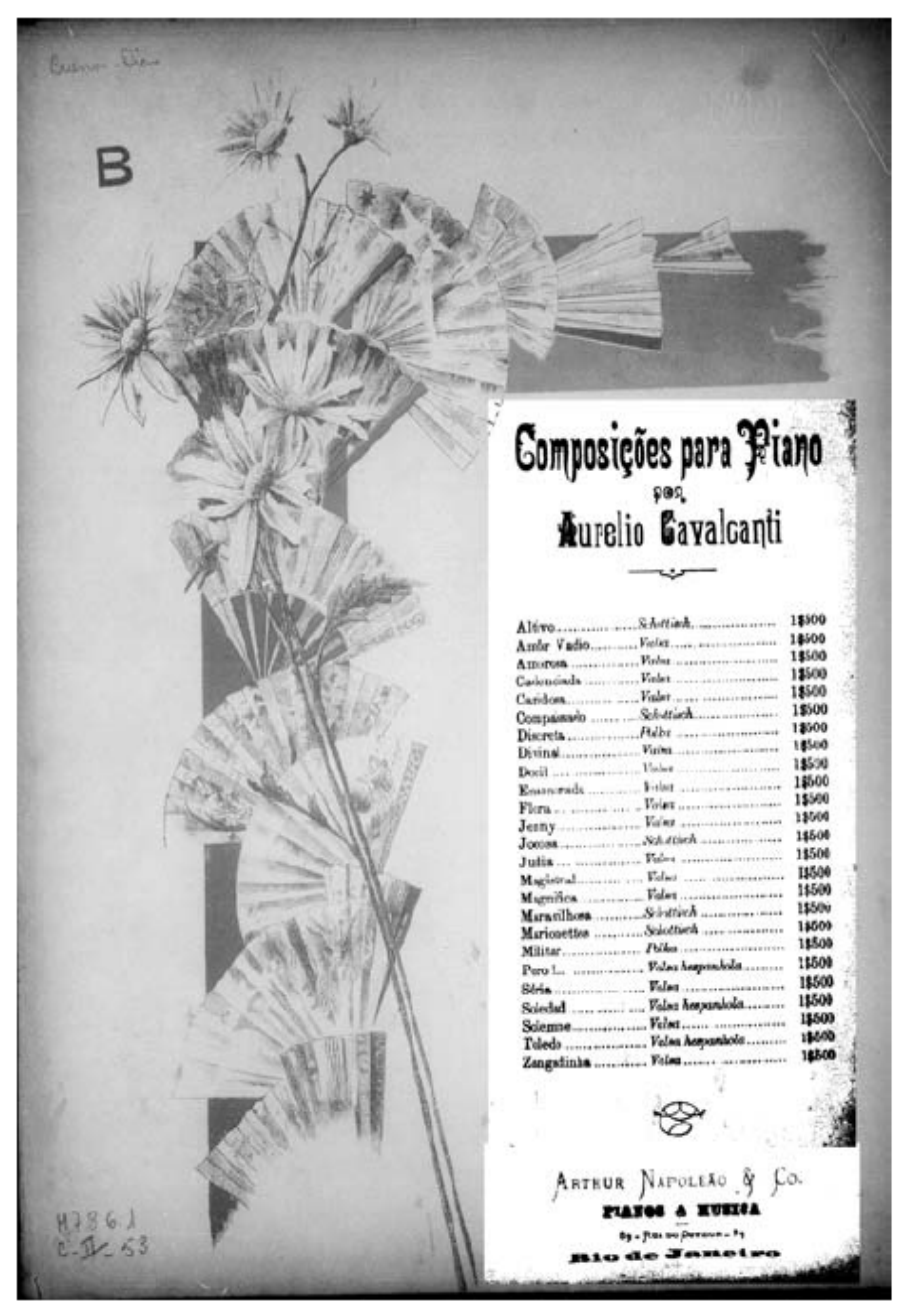

Ex. 6 - Capa de "Buenos dias", valsa hespanhola, de Cavalcanti. Biblioteca Nacional de Rio de Janeiro, Divisão de Música e Arquivo Sonoro.

Como muitos na Paris de seu tempo, Cavalcanti e seu público eram fascinados pela música espanhola. Vista como um Outro no interior da própria Europa, a Espanha já tinha sido frequentemente evocada em peças europeias de diferentes gêneros e estilos através de uma sintaxe bem definida de "espanicidade"24 (SCOTT, 1998, p.309-35). "Buenos Dias", uma das muitas Valsas hespanholas compostas por Cavalcanti, serve como um exemplo conspícuo de um exotismo sendo reciclado fora do domínio europeu, pois ela reúne todos os elementos musicais necessários para marcar sua diferença com relação à sua polca francesa "Bregeira": os deslocamentos rítmicos da melodia, acentuando o segundo tempo na primeira seção, o uso das tercinas e as sugestões do modo frígio na melodia durante a terceira seção,

\footnotetext{
24 No original, Spanishness [N. do T.]

MAGALDI, Cristina. Cosmopolitismo e world music no Rio de Janeiro na passagem para o século XX. Música Popular em Revista, Campinas, ano 1, v. 2, p. 42-85, jan.-jun. 2013.
} 
ao mesmo tempo em que utiliza uma progressão harmônica que ajuda a reiterar a "francesidade"25 da dança. O conhecimento de Cavalcanti de uma sintaxe de "espanicidade" à la Chaminade e Waldteufel é bastante significativo, pois sua Valsa hespanhola não é apenas uma homenagem ao local dado por um título sugestivo, mas apresenta um uso consciente de códigos musicais de exotismo que era dependente da familiaridade do compositor e de seu público com os modelos europeus para fazerem sentido.
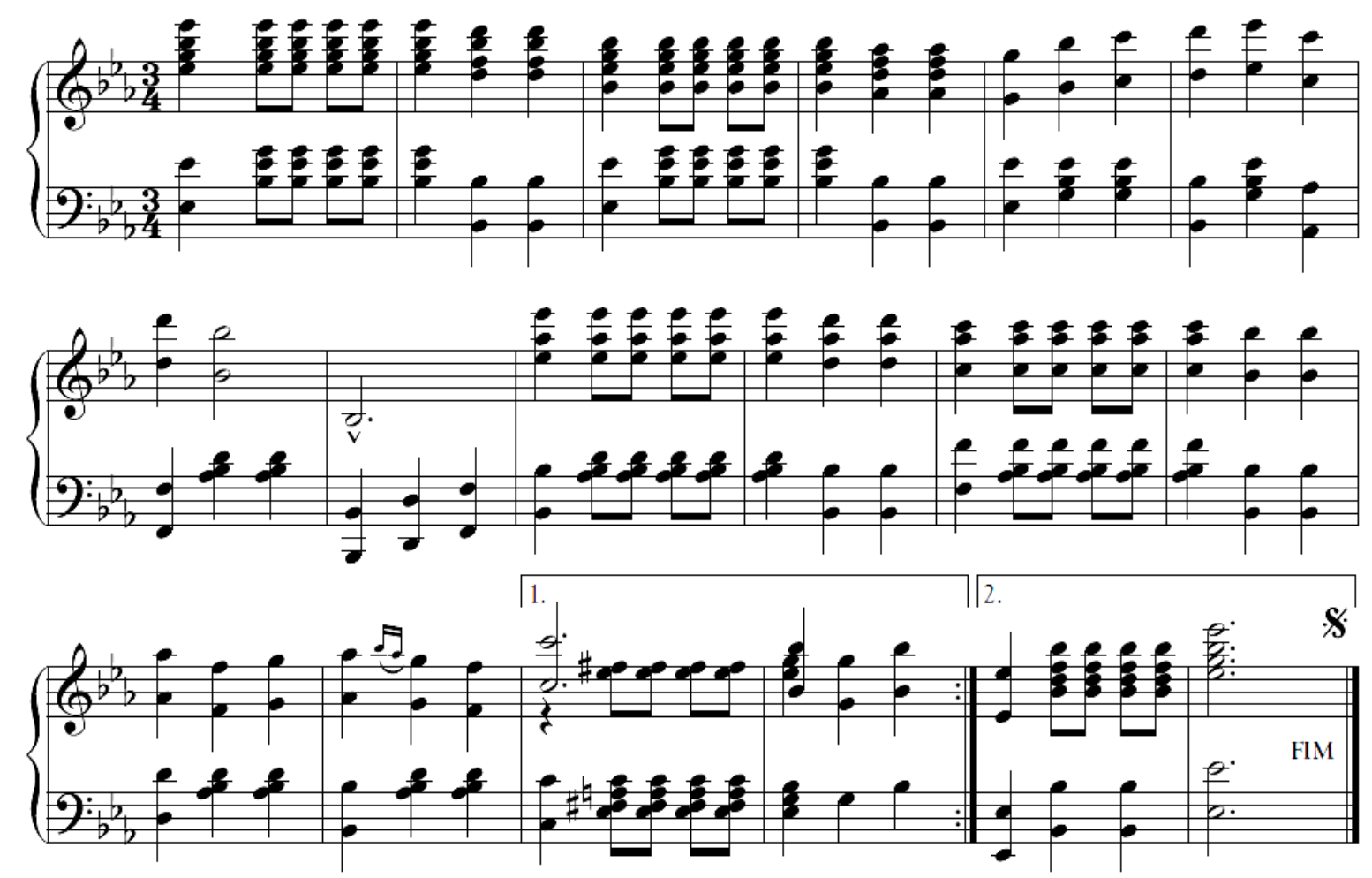

Ex. 7 - Aurélio Cavalcanti, "Buenos dias", valsa hespanhola (c. 1903) (Rio de Janeiro: Arthur Napoleão e Co.). Biblioteca Nacional do Rio de Janeiro, Divisão de Música e Arquivo Sonoro.

${ }^{25}$ No original, Frenchness [N. do T.]

MAGALDI, Cristina. Cosmopolitismo e world music no Rio de Janeiro na passagem para o século XX. Música Popular em Revista, Campinas, ano 1, v. 2, p. 42-85, jan.-jun. 2013. 

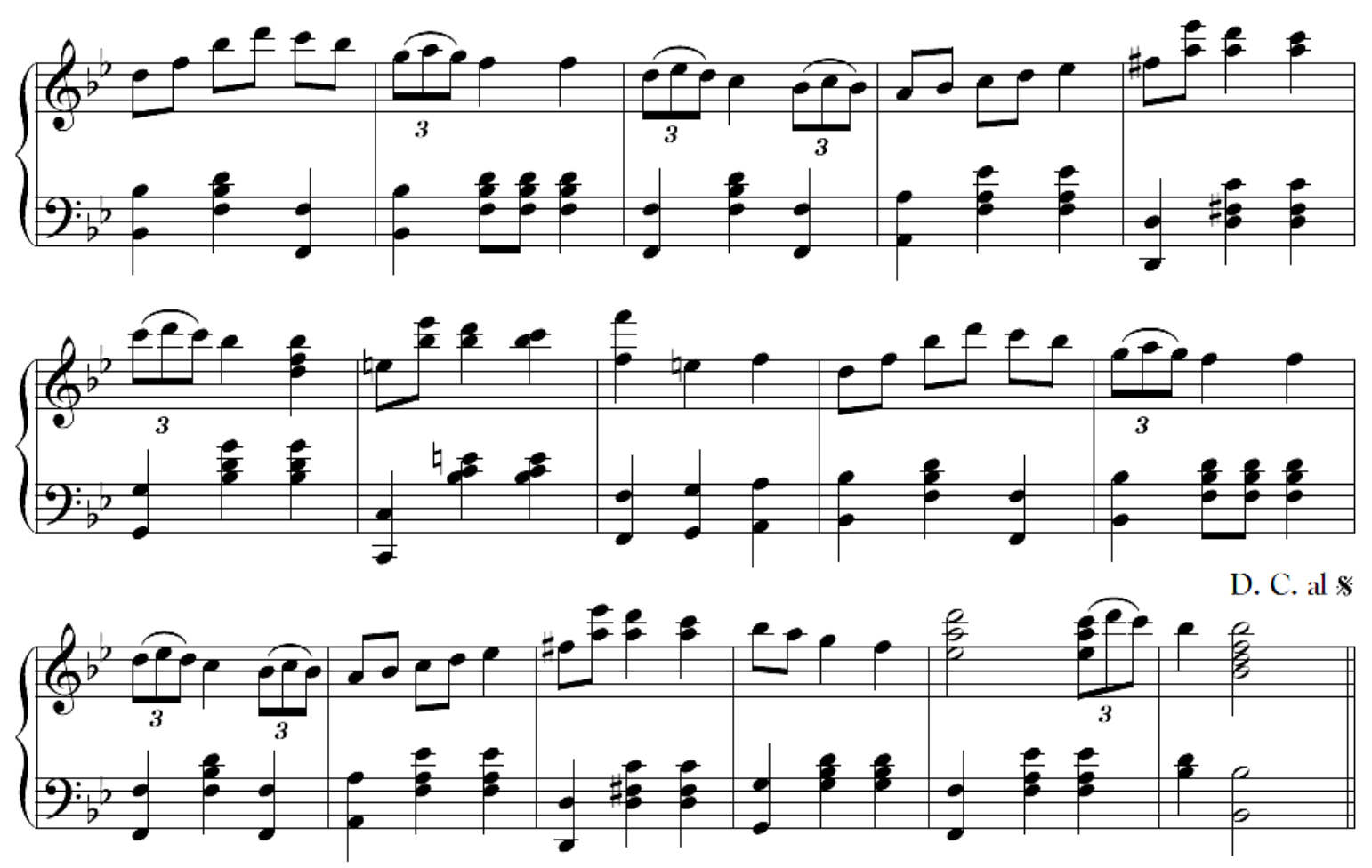

Ex. 8 - Aurélio Cavalcanti, "Buenos dias", valsa hespanhola (c. 1903) (Rio de Janeiro: Arthur Napoleão e Co.). Biblioteca Nacional do Rio de Janeiro, Divisão de Música e Arquivo Sonoro.

"Buenos dias" de Cavalcanti pode ser vista como mais do que uma peça exótica que caracteriza a dualidade entre identidade e alteridade; ela é um trabalho que demonstra as habilidades de Cavalcanti de reproduzir as construções francesas de diferença, uma posição cosmopolita que o ajudou a articular uma variedade de Outros sem evidenciar sua própria condição periférica. Posicionado como insider e outsider, o cosmopolitismo de Cavalcanti é marcado por sua habilidade de se envolver com a música de várias localidades e etnicidades através de seu entendimento de uma linguagem musical central derivada dos centros urbanos da Europa. Deste modo, sua "Valsa sertaneja", na qual ele faz referência a um estilo regional brasileiro, pode ser interpretada da mesma forma que sua polca "Bregeira" ou sua valsa "Buenos dias", como uma exploração de uma cultura cosmopolita passada para ele através dos imaginários europeus de alteridade.

Como um cosmopolita na periferia, Cavalcanti foi capaz de oferecer às audiências do Rio de Janeiro a imagem mais ampla possível do mundo sonoro, e esta vasta palheta incluía as regiões mais próximas. De fato, um grande número de 
canções e danças do século XIX eram relacionadas a localidades específicas, senão por códigos musicais, por títulos sugestivos como "Polka Madrid", "La parisienne", "The Yankee", ou "Valsa Sertaneja". Estes trabalhos demonstram que os "locais", próximos ou mais distantes, eram usados como importantes ferramentas de marketing para ampliar o interesse nas peças populares, aumentando a circulação nos mercados maiores com o potencial concomitante para grandes lucros - títulos e códigos musicais de alteridade funcionavam como um tipo de ornamentação que trazia interesse para os trabalhos como sendo peças exóticas. Entretanto, a localidade associada a estas danças também envolveu uma expectativa de um estilo em comum entre elas - o estilo musical popular das metrópoles europeias. Para estas peças fazerem sentido, elas precisavam primeiramente seguir uma linguagem comumente aceita como cosmopolita - precisavam ser facilmente reconhecíveis como valsas ou polcas, por exemplo - e só depois disso elas poderiam funcionar como mercadorias abertas a negociações para servir a outros significantes de identidade. A aptidão de Cavalcanti em escrever valsas e polcas realça sua posição como participante da linguagem musical internacional compartilhada por outros em Buenos Aires, Nova York, Londres e Paris; isso demonstra uma grande consciência do compositor brasileiro de um mundo de conexões musicais internacionais.

Não se trata aqui de um simples exercício de modelos e derivativos, de uma discussão estética que elogia o que é autêntico e rejeita a réplica, ou ainda que destaca o processo de reinvenção das danças europeias como composições brasileiras originais. Meu argumento se baseia na natureza das peças de Cavalcanti, que foram escritas de modo a preencher um espaço que era local (Rio de Janeiro), mas através de uma linguagem musical que era cosmopolita. Deste modo, não seria errada a caracterização das polcas e valsas de Cavalcanti como uma imitação bem-sucedida das danças de Waldteufel no e para o Rio de Janeiro. Reitera-se aqui que a ideia de centro versus periferia é evidente neste caso, já que as obras de Waldteufel ou de Strauss estavam circulando no Rio de Janeiro, enquanto as danças de Cavalcanti não seguiam um caminho recíproco em Paris ou Viena. Todavia, não se pode excluir a possibilidade de que, se o compositor brasileiro se estabelecesse em Paris, Nova York ou Buenos Aires, ele teria obtido sucesso como compositor para os salões de dança 
em qualquer uma destas cidades. Desse modo, o sucesso do trabalho de Cavalcanti como compositor de polcas e valsas no Rio de Janeiro reside não na singularidade das suas composições, nas suas marcas de diferença local, mas na sua habilidade de atender às demandas do público local para se situar em uma genérica e de certa forma abstrata cidade em crescimento na virada do século XX.

\section{Orientalismo no Rio de Janeiro na passagem para o século XX}

Assim como no mercado musical de hoje, na passagem para o século $X X$, novidade e variedade eram fatores essenciais para o sucesso do comércio de músicas destinadas a um elevado número de pessoas em diferentes cidades. Os music halls de Londres e os cafés concertos e cabarés parisienses com uma clientela diversificada eram espaços ideais para se prover a variedade, a mistura e a experimentação. Além disto, os empresários também dependiam de uma grande variedade de estilos musicais para ornamentar as performances no teatro de variedade, em comédias, apresentações circenses e teatrais. Como o súbito sucesso comercial destas performances coincidiu com o ápice do imperialismo europeu no século XIX, a variedade musical nesses espaços era conseguida também com a apresentação de peças internacionais. Em pequenos palcos de Paris e Londres, músicas e danças eram usados para representar uma variedade de lugares colonizados, para retratá-los como exóticos e então apresentar o exótico como uma tendência de moda; no processo, a re-criação e adaptação de canções e danças de lugares próximos e distantes tornaram-se uma prática comum (WHITING, 1999, p.24). Nesses recintos, danças populares e canções alimentavam a curiosidade e o interesse sobre culturas externas à burguesia europeia branca e urbana, ao mesmo tempo em que contribuíam para a construção de uma dinâmica complexa entre localidade e alteridade musical em áreas urbanas, dentro e fora da Europa. Essa dinâmica envolvia não apenas a comercialização de músicas populares como tendências exóticas de moda, mas também a articulação de uma sintaxe musical de exotismo que poderia, por sua vez, ser útil para articular políticas locais de classe, raça e gênero. Essa sintaxe era um conjunto genérico de ferramentas musicais, criado na 
Europa, como representação do exótico (SCOTT, 1998, p.320) e era frequentemente apresentado em atuações de comédia, abrindo espaço para caricaturas e paródias. Por volta do final do século, compositores e editores musicais europeus haviam despertado para o apelo internacional do elemento exótico em músicas populares, apelo este que se estabelecia tanto em articulações de uma identidade comum, urbana e cosmopolita traduzida como sendo global - como em articulações de uma noção complementar sobre uma "alteridade global"26 (HICK, 2003). Até certo ponto, o fenômeno se equipara ao apelo que o segmento mercadológico da world music exerce sobre a música popular atual (nos Estados Unidos e Europa Ocidental), alimentado como tem sido por ideais essencialistas da autenticidade do Outro, resignificado como tendência de moda, urbana e cosmopolita.

O interesse em representar a música de "terras distantes", transformandoa em tendência de moda que pode ser comercializada, já estava em voga no mundo da música lírica da ópera - e tinha sido um agente musical fundamental na expansão imperialista da Europa - quando mais tarde foi explorada na comercialização das músicas populares. Entretanto, foi a novidade dos filmes que permitiu uma difusão mais internacional da world music. Saturados com imagens de terras distantes, os primeiros sucessos da filmografia francesa e norte-americana eram amplamente acessíveis no Rio de Janeiro, desde 1896; em 1905, eles já haviam garantido um sólido espaço no mercado de entretenimento da capital brasileira. Anunciados diariamente nos jornais do Rio como “da moda, novos, modernos" (JORNAL..., 1901), os primeiros filmes com coleções de vistas (imagens), levaram os moradores do Rio a um passeio visual em terras distantes (CONDE, 2005, p.67). A importação destes primeiros filmes era mais barata do que o custeio de produções locais, não apresentavam barreiras da língua, pois eram mudos e serviam como um importante meio de proliferação de canções e danças de lugares exóticos, que acompanhavam as imagens projetadas na tela.

No domínio do teatro musical, Gilbert e Sullivan e Sidney Jones foram particularmente bem sucedidos ao trazerem o Oriente como o Outro para as plateias metropolitanas da Europa e das Américas. Enquanto Mikado (1885) retratava o Japão

\footnotetext{
${ }^{26}$ No original, "otherworldliness" [N. do T.]

MAGALDI, Cristina. Cosmopolitismo e world music no Rio de Janeiro na passagem para o século XX. Música Popular em Revista, Campinas, ano 1, v. 2, p. 42-85, jan.-jun. 2013.
} 
como um lugar agradável através de canções familiares, seu êxito foi ultrapassado por Geisha (1896), de Jones, a qual se tornou um súbito sucesso em teatros nos dois lados do Atlântico. Índia e China também serviram como excelentes lugares a partir dos quais compositores Europeus puderam obter fontes para construir "uma sintaxe musical do exotismo oriental", como Scott (1998, p.309-35) demonstrou. A peça musical de Jones San Toy: A Chinese Musical Comedy (1899) foi consideravelmente bem sucedida, no entanto, A Chinese Honeymoon (1899), de Howard Talbot, é considerada a mais difundida das peças que estereotipavam os chineses na passagem para o século $X X^{27}$. O sucesso dessas obras nos dois lados do Atlântico, conforme sugeriu William Hick, não era simplesmente um "voyeurismo" cultural, mas antes uma moda que se tornou possível exatamente porque as plateias urbanas viam o Oriente como um exótico local, ao mesmo tempo, perto e distante. Essas obras serviram com fonte, onde se experimentavam elementos exóticos que, na realidade, estavam bem próximos (HICK, 2003, p. 5). Nessas obras teatrais, a música com "sonoridade oriental" podia ser criada por qualquer combinação de ferramentas musicais que se tornariam rapidamente dispositivos formulaicos, uma sintaxe musical do Outro, como notou Derek Scott (1998, p. 22, 27), usada por compositores de várias cidades para transformar em exótico e criticar, ao mesmo tempo, aqueles que estavam próximos e aqueles que estavam distantes ${ }^{28}$.

Embora Edward Said (1994, p.71-2) tenha afirmado que os orientalismos foram criados para plateias na Europa e "apenas para a Europa", a consciência e o uso da sintaxe musical oriental/exótica não ficou na Europa. Na realidade, na virada do século XX, o Oriente exótico se inseriu no mercado musical internacional com enorme força. Esse fenômeno foi alimentado pela ideia de uma tendência de moda da "alteridade musical", que juntamente com valsas e polcas, proporcionava às plateias urbanas uma cultura cosmopolita comum. Como era de se esperar, após seu sucesso em Londres e na Broadway, em 1901, a peça San Toy, de Jones, também teve uma bem sucedida estreia no Rio de Janeiro. Num momento em que os políticos brasileiros estavam discutindo a possibilidade de usar a mão-de-obra chinesa para

${ }^{27}$ HICK, 2003, p.10. San Toy, de Jones, teve 768 apresentações no Daly's Theater de Londres, em 1899 (SAN, s.d.).

28 Ver também HICK, 2003, p. 5, 42 e 49.

MAGALDI, Cristina. Cosmopolitismo e world music no Rio de Janeiro na passagem para o século XX. Música Popular em Revista, Campinas, ano 1, v. 2, p. 42-85, jan.-jun. 2013. 
substituir a africana, e quando "imagens da China 'flutuavam' como um fantasma onipresente através de discussões sobre etnicidade no Brasil" (LESSER, 1999, p. 14, 15 e 23), o êxito de San Toy na capital brasileira foi também alimentado pela linha frágil entre os problemas e fatos que se viam como distantes e como locais. Não foi por coincidência que canções e danças populares exóticas marcaram presença na capital brasileira ao mesmo tempo em que intelectuais brasileiros se ocupavam em mapear o perfil racial e étnico do país. E, enquanto orientalismos musicais chegavam na cidade como tendências de moda, de valores cosmopolitas de mundos distantes, compositores brasileiros assumiram a tarefa de fornecer ao próspero mercado musical do Rio de Janeiro suas próprias fantasias do Oriente.

Assim como Cavalcanti, o compositor Nicolino Milano (1876-1962) fez uso das ferramentas musicais a sua disposição, movendo-se rapidamente entre localidade, o cosmopolitismo e a moda através de uma longa lista de canções e danças. Natural de São Paulo, Milano estudou e viveu durante a maior parte de sua vida no Rio de Janeiro, onde ele foi um ativo violinista e compositor. Estudou no Instituto Nacional de Música com músicos proeminentes, como Vicenzo Cernichiaro e Miguel Cardoso, e, mais tarde, também trabalhou como professor naquela instituição. Como Cavalcanti, Milano foi um artista que trabalhou bem tanto no cenário da arte musical da elite, quando no mercado da música popular; atuou com Barroso Netto e Alberto Nepomuceno em concertos, ao mesmo tempo em que tocava na noite, no Café Java ${ }^{29}$. Como compositor, Milano foi mais bem sucedido ao escrever música para teatro, trabalhando com os mais prestigiosos autores de comédias musicais na capital brasileira. Milano é mais conhecido pela música que escreveu para a famosa revista de Arthur Azevedo A Capital Federal (1897), mas o compositor também deixou um grande número de polcas, valsas, danças espanholas, tangos e outras obras que o colocam no centro das modas musicais populares de sua época. Sua canção "Ti-fá" (versos de Orlando Teixeira), escritas para a opereta "chinesa" Tifá, serve de excelente exemplo de como a ideia de world music foi reciclada dentro da perspectiva de um compositor latino-americano (ver Ex. 9-10).

\footnotetext{
29 Para mais informações sobre Milano, ver BISPO, 2007 e WEHRS, 1980, p. 104-5. 


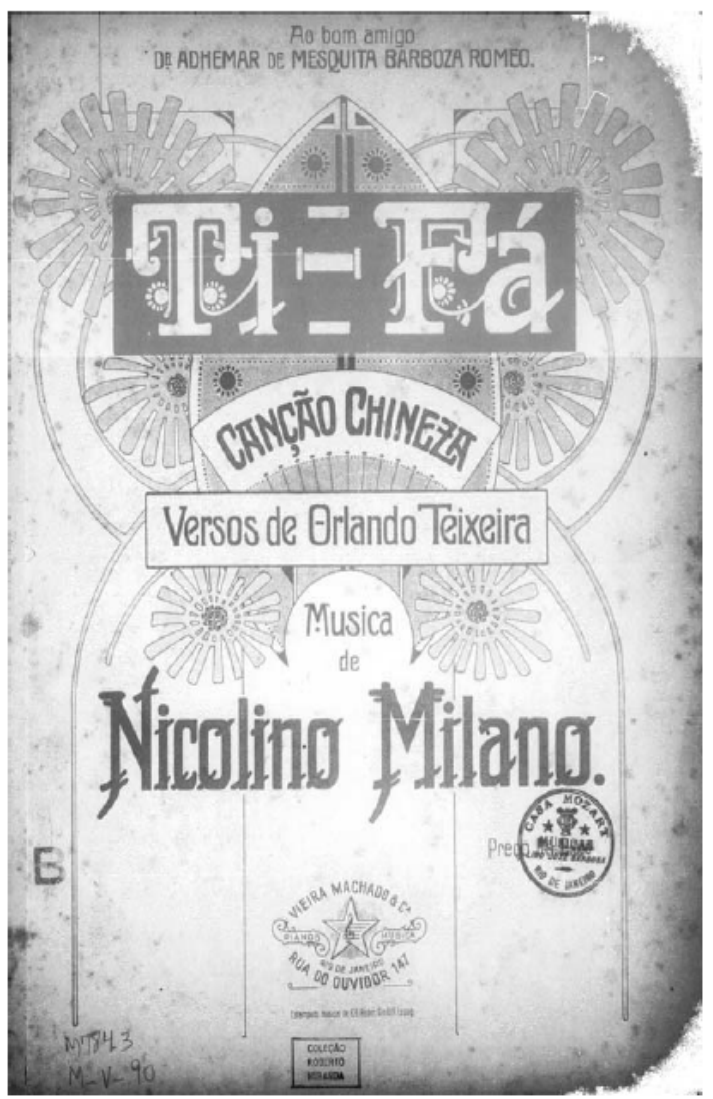

Ex. 9 - Capa de "Ti-fá", de Nicolino Milano, da opereta Ti-fá. Biblioteca Nacional do Rio de Janeiro, Divisão de Música e Arquivo Sonoro.

A canção mostra Milano primando-se na manipulação de clichês musicais conhecidos, passando de um lado para o outro entre os valores de alteridade de vários mundos, perto e longe, como os melhores compositores de seu tempo. A obra tem signos musicais de alteridade em abundância, no seu emprego de significantes musicais do orientalismo, como uma abertura em uníssono, o uso de quartas paralelas e oitavas, o uso de trilos no estilo do glissando, com quintas justas funcionando como sons contínuos na primeira seção. Na segunda parte, Milano explora a segunda aumentada como elemento exótico ao adicionar o dó sustenido na appoggiatura, mas muda de menor para maior, voltando confortavelmente para a cadência tonal definida, um movimento que desloca ainda mais o início "oriental" de sua canção chinesa. Por um lado, a peça de Milano precisava articular o Oriente como o Outro exótico para fazer sentido dentro dos correntes debates políticos internos sobre a mão de obra chinesa, raça e nacionalidade no Brasil. Por outro lado, o "Ti-fá" de Milano precisava ser cosmopolita e estar na moda, situando-se entre diversas outras canções que pertenceram a seu tempo e à sua cidade. É significativo o 
fato de que a peça de Milano não seja um caso único no contexto do Rio de Janeiro, já que exemplos de orientalismos em canções e danças populares escritas por seus contemporâneos eram abundantes na capital brasileira neste período. Um exemplo convincente é fornecido pelo famoso pianista e compositor Julio Reis (1870-1935), outra figura proeminente da vida noturna do Rio de Janeiro. Como Cavalcanti e Milano, Reis foi prolífico na escrita de valsas, polcas e schottisches, mas também deixou uma peça muito intrigante intitulada "Scenas Orientais", na qual uma completa gama de estereótipos é habilidosamente misturada para demarcar localmente não somente o Oriente, como o Outro brasileiro, mas também o compositor brasileiro como um artista cosmopolita (ver Ex. 11).

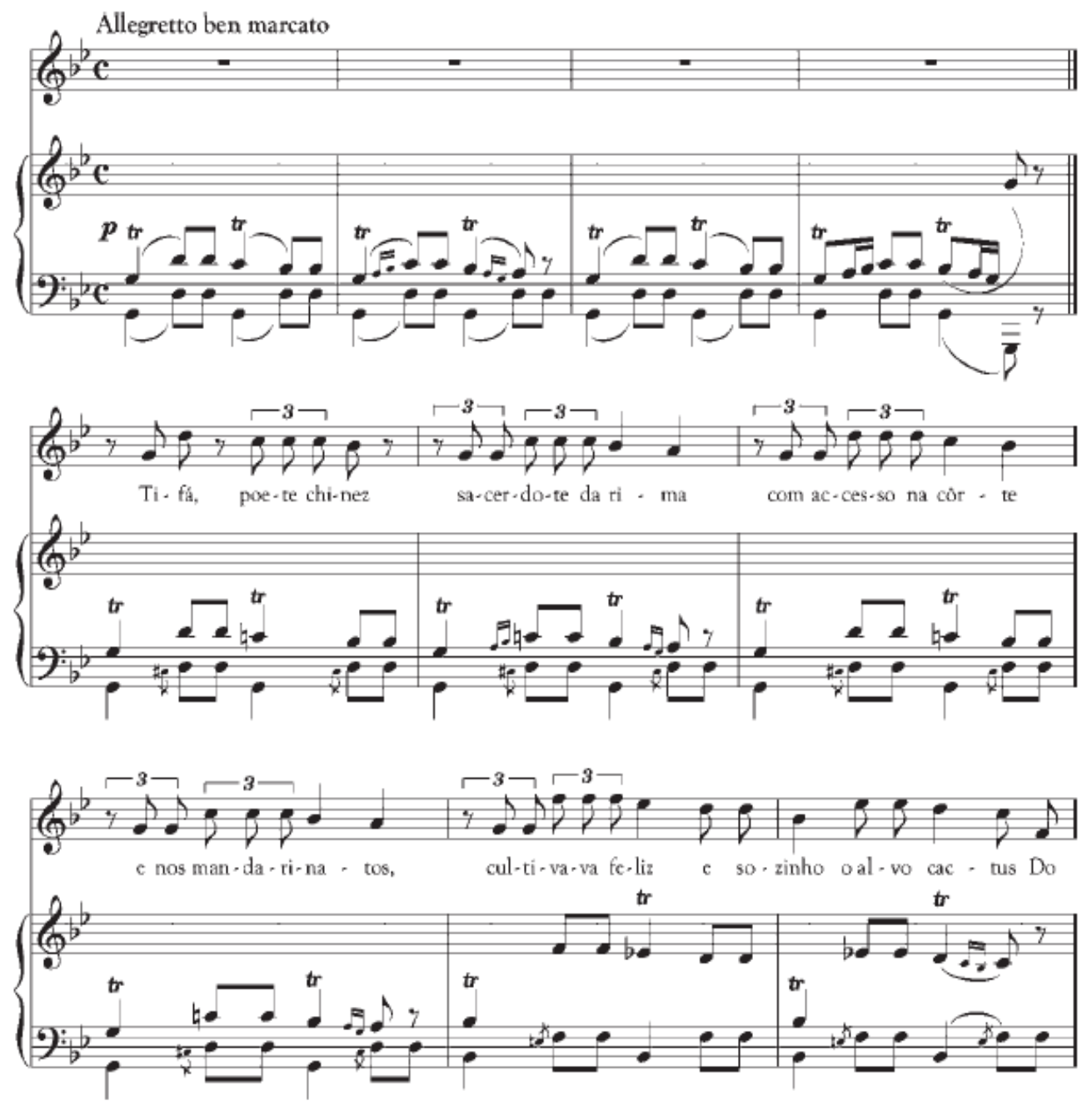

Ex. 10 - Nicolino Milano, "Ti-fá", canção chineza (c. 1908) (Rio de Janeiro: Vieira Machado E Cia.) Biblioteca Nacional do Rio de Janeiro, Divisão de Música e Arquivo Sonoro. 

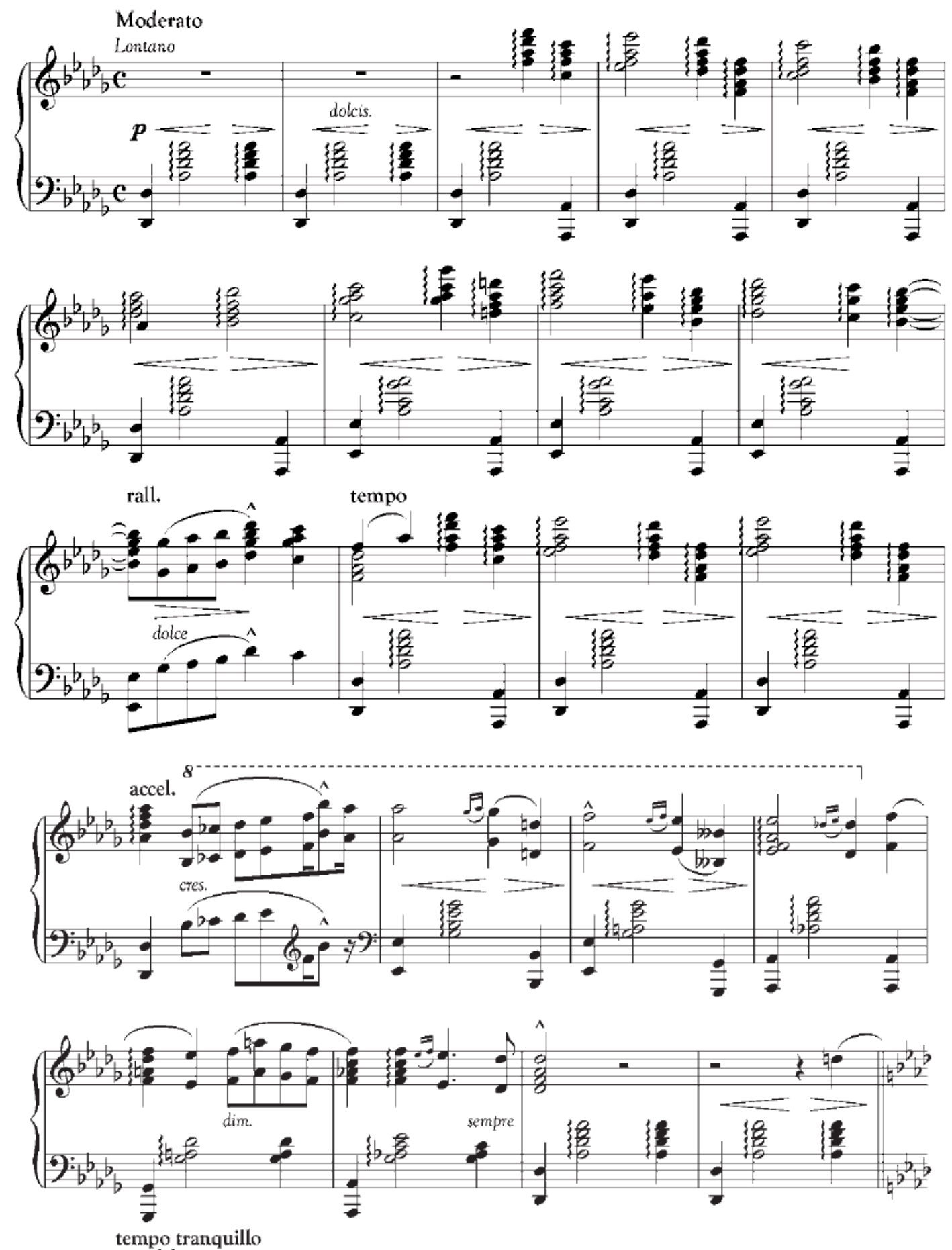

tempo tranquillo

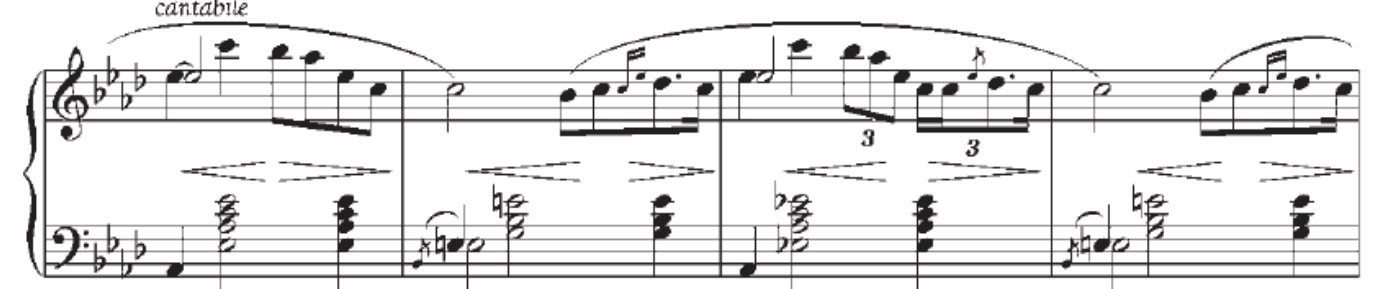

Ex. 11 - Julio Reis. "Scenas orientais" (c. 1908) (Rio de Janeiro: Casa Vieira Machado). Biblioteca Nacional do Rio de Janeiro, Divisão de Música e Arquivo Sonoro. 


\section{"Branqueando" a população e "enegrecendo" a música}

Em 07 de julho de 1903, o imigrante italiano Paschoal Segreto apresentou no Rio de Janeiro o filme francês Le cake-walk infernal (1903) de Georges Méliès (18681938). O filme incluía cenas da dança do cakewalk, que tinha se tornado uma moda em Nova Iorque e em Paris e, assim, a dança foi adicionada no potpourri das musicas disponíveis aos residentes da capital do Brasil. Aproximadamente um mês depois a "famosa" cakewalk apareceu ao lado das canções francesas e peças de San Toy, de Jones, em um espetáculo de music hall local como mais um produto cosmopolita com apelo internacional. No início de fevereiro do mesmo ano, a primeira página de um proeminente jornal local já tinha comentado sobre a mania do cakewalk na Europa, antecipando seu sucesso no Rio de Janeiro. De acordo com o artigo, o cakewalk

originou-se entre os negros americanos (os quais) juntos em bares, formam um círculo, e ao som do banjo, realizam saltos excêntricos e movimentos com a perna ao redor de um bolo. ( $\mathrm{O}$ cakewalk então se estendeu) para os café-concertos [...] tornando-se universal, graças à chamada Americanização do Mundo. (CORREIO, 1903).

$\mathrm{O}$ comentarista não estava exagerando, pois o cakewalk e o ragtime se espalharam muito facilmente pelo circuito musical internacional de Nova Iorque a Paris, Londres, Rio de Janeiro, e outras cidades da América Latina, como uma epidemia. ${ }^{30,}$ Em uma época em que o poder econômico e político dos Estados Unidos estava crescendo em um ritmo acelerado, o status "universal" do cakewalk e de outras danças e canções, como o ragtime e o two-step, ajudaram a expandir o circuito cultural urbano cosmopolita e incluir cidades como Nova Iorque e Chicago.

O sucesso de canções e danças de cakewalk e ragtime no Rio de Janeiro refletiam a continuação de uma tendência na música popular urbana de representar a música e cultura negras pelos europeus. Enquanto exemplos destas representações apareciam nas músicas e peças teatrais europeias desde o século XVIII, o apelo do elemento negro teve uma guinada internacional com o sucesso dos shows de menestréis nos Estados Unidos e na Europa na metade do século XIX, e posteriormente com o sucesso das performances de John Philip Sousa na Europa,

30 De acordo com Gonzaléz (2005, p.81), o cakewalk também obteve sucesso em Santiago (Chile) no início do século XX.

MAGALDI, Cristina. Cosmopolitismo e world music no Rio de Janeiro na passagem para o século XX. Música

Popular em Revista, Campinas, ano 1, v. 2, p. 42-85, jan.-jun. 2013. 
incluindo ragtimes and cakewalks. As canções de menestrel de Stephen Foster, por exemplo, eram tão populares dentro e fora dos Estados Unidos que sua "Old Folks at Home" serviu como inspiração para as "Manhattan Waltzes" de Johann Strauss Jr., durante o período em que o compositor vienense visitou os Estados Unidos (SCOTT, 2008, p. 52). À medida em que os afro-americanos começavam a obter o controle dos seus negócios no final do século XIX, eles abriram novas possibilidades para a popularização dos musicais all-black em Nova York, como o Creole Show (1890), que incluía a dança do cakewalk, o Oriental America (1896) e A Trip to Coontown (1898). A música dos menestréis era particularmente popular em Londres, onde já em 1865 havia uma trupe local permanente de menestréis. A fascinação britânica pela música afro-americana como um novo Outro exótico pode também ser vista na peça Utopia Unlimited $^{31}$ (1893), de Gilbert e Sullivan.

Não demorou para Londres se transformar em centro de produções de partituras de música de menestréis, competindo com Nova York, uma vez que a música tinha se tornado mais uma moda cosmopolita atraente que cruzava fronteiras. As canções dos menestréis e os cakewalk, já uma mania na Broadway em 1890, foram apresentados repetidamente nos palcos de Londres e Paris no começo do século XX. A mania foi intensificada em Paris pelos concertos de John Philip Sousa, nos quais eram incluídas canções de menestréis e ragtime, assim como o cakewalk. Enquanto a dança crescia numa febre internacional, ela inspirou a produção parisiense, no famoso palco do Nouveau Cirque de Joyeux nègre, "Grand America Nautical Pantomime" (1902). O show inspirou o compositor Rodolphe Berger a escrever seu cakewalk "Joyeux Nègres" (1903) (WHITING, 1999, p. 297-8). A mania pela música popular afro-americana na Europa também alimentou a vanguarda em Paris, na passagem para o século XX, desde os trabalhos de artes plásticas, esculturas e na literatura, até o mundo da elite musical; o "Golliwog's Cakewalk" de Debussy (1906-08) é um exemplo muito conhecido de como o elemento negro tido como exótico e reposicionado como afro-americano enraizou-se na cultura parisiense (BLAKE, 1999, p. 252).

\footnotetext{
${ }^{31}$ HICK, 2003, p. 63-70. Ver também no texto de McKinley (1986, p. 252). 
Não foi uma coincidência, portanto, que a ideia da síncope presente nas canções dos menestréis se tornasse uma força definidora da música popular afroamericana na segunda metade do século XIX. Como Scott observou, ao lado de estruturas musicais idiomáticas como "pergunta e resposta" e de sugestões de melodias pentatônicas, uma maneira particular de síncope - com um acento na nota imediatamente anterior à nota sincopada - se tornariam alguns dos significantes mais importantes das músicas populares afro-americanas (SCOTT, 2008, p. 149-57). Combinados, esses elementos permitiram o desenvolvimento de uma sintaxe de Africanismos na música popular que se somaram à já então difundida sintaxe dos Orientalismos. Enquanto que esses Africanismos eram parte da "revolução da música popular" do final do século XIX, eles precisavam ser vistos dentro dos parâmetros do contexto cosmopolita que tinha a burguesia européia branca como ponto de referência. Antes de se tornarem uma febre das modas urbanas, eles foram apresentados em atos de comédias populares e descartados como paródias. Como Scott aponta, tanto os músicos afro-americanos quanto os brancos estavam remodelando as suas músicas umas nas dos outros, para alcançar suas próprias demandas estéticas, mas o estavam fazendo

\begin{abstract}
dentro de um sistema de relações de poder desiguais, nas quais o músicos branco podia definir a natureza da música negra e dominar sua recepção, deixando o músico negro com uma identidade em conflito com relação à sua subjetividade [...]. Os afro-americanos ficaram sem o controle dos meios para representar a si próprios no palco (SCOTT, 2008, p. 154).
\end{abstract}

Se por um lado, a participação de músicos negros na produção e na performance deste tipo de música dava a eles alguma autoridade sobre um mercado em expansão, por outro lado, a sua presença adicionava, ironicamente, uma "autenticidade" que a música necessitava para ser deslocada, mais uma vez, como o Outro exótico. Então, deve-se enfatizar que a celebração dos Africanismos na música popular deste período precisa ser compreendida historicamente como uma consequência direta do colonialismo europeu, com suas evidentes hierarquias raciais e ideologias racistas ${ }^{32}$. Mesmo assim, a produção, a performance e o consumo dessas

\footnotetext{
32 Kofi Agawu argumenta que a ideia dos Orientalismos como estrutura musical pode ser visa de forma paralela à dos Africanismos, se não considerarmos o uso de Melville Herskovits do termo MAGALDI, Cristina. Cosmopolitismo e world music no Rio de Janeiro na passagem para o século XX. Música Popular em Revista, Campinas, ano 1, v. 2, p. 42-85, jan.-jun. 2013.
} 
músicas operavam dentro de sistemas complexos maiores. Em termos de políticas de representação e de relações sociais, étnicas e raciais entre os dois lados do Atlântico, os limites entre identidade local e alteridade se tornaram complicados, obscuros, e por vezes irrelevantes. De fato, quando se examina os Orientalismos e os

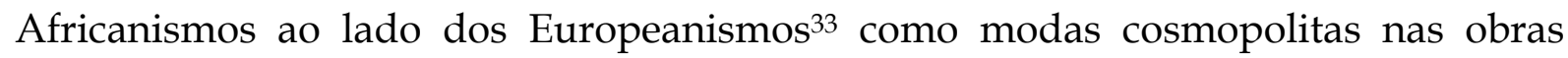
populares da época, as similaridades entre as sintaxes se tornam tão significantes quanto as diferenças.

Quando o cakewalk e o ragtime começaram a trilhar seus caminhos em direção à cena musical do Rio de Janeiro, foi o seu status como música popular internacional representando as práticas musicais negras filtradas através do mercado branco de música que atraiu o público para a capital brasileira. Assim, não deveríamos nos surpreender ao encontrar compositores locais também escrevendo canções de menestréis, cakewalks e ragtime, para fazer parte do circuito musical cosmopolita. A música "Old Folks at Home", de Foster, por exemplo, reaparece disfarçada em arranjos instrumentais locais, como em "CakeWalk, Georgia Marcha", para bandolim e piano por Eugenio Orfeo (publicado por E. Bevilaqua, Rio de Janeiro).

A novidade do cakewalk também interessou ao compositor Aurélio Cavalcanti, que viu na dança uma nova maneira de apelo para o público cosmopolita do Rio de Janeiro (ver Ex. 11-2). O “Cake-walk" de Cavalcanti é uma marcha com a mesma estrutura de dança de suas polcas, três seções que se repetem. A peça, que mostra uma semelhança inequívoca com o cakewalk de Berger, "Joyes nègres” inclui o traço já estabelecido de síncopes ininterruptas na melodia que enfatizam o primeiro tempo da marcha, ao invés da nota sincopada, com a sugestão adicionada de pentatonismo na melodia. Ao mesmo tempo, o compositor faz uso da sexta acrescentada na melodia, evocando novamente as valsas vienenses, tão em moda. $\mathrm{O}$ uso de acordes acentuados e sincopados por Cavalcanti na segunda seção também lembra seu uso de acordes acentuados na segunda seção da sua Valsa hespanhola, ambas servindo para destacar o elemento

Africanismo para se referira às práticas musicais derivadas da África no novo Mundo. Ver AGAWU, 2003, p. 95.

${ }^{33}$ No original, Europeanisms. [N. do T.]

MAGALDI, Cristina. Cosmopolitismo e world music no Rio de Janeiro na passagem para o século XX. Música Popular em Revista, Campinas, ano 1, v. 2, p. 42-85, jan.-jun. 2013. 
de surpresa em suas seções intermediárias. No seu "Cake-walk", Cavalcanti mostra-se consciente que a síncope era necessária para definir os africanismos da obra como um elemento exótico, mas ele foi rapido em combina-la com diferentes Outros, como suas polcas francesas ou suas valsas espanholas. Os africanismos de Cavalcanti, traduzidos em sincopação, eram elementos adicionados a suas ferramentas cosmopolitas de alteridade de vários mundos, perto e longe, que situaram a sua música, assim como seu público, como parte de uma grande paisagem sonora urbana ao final do século.

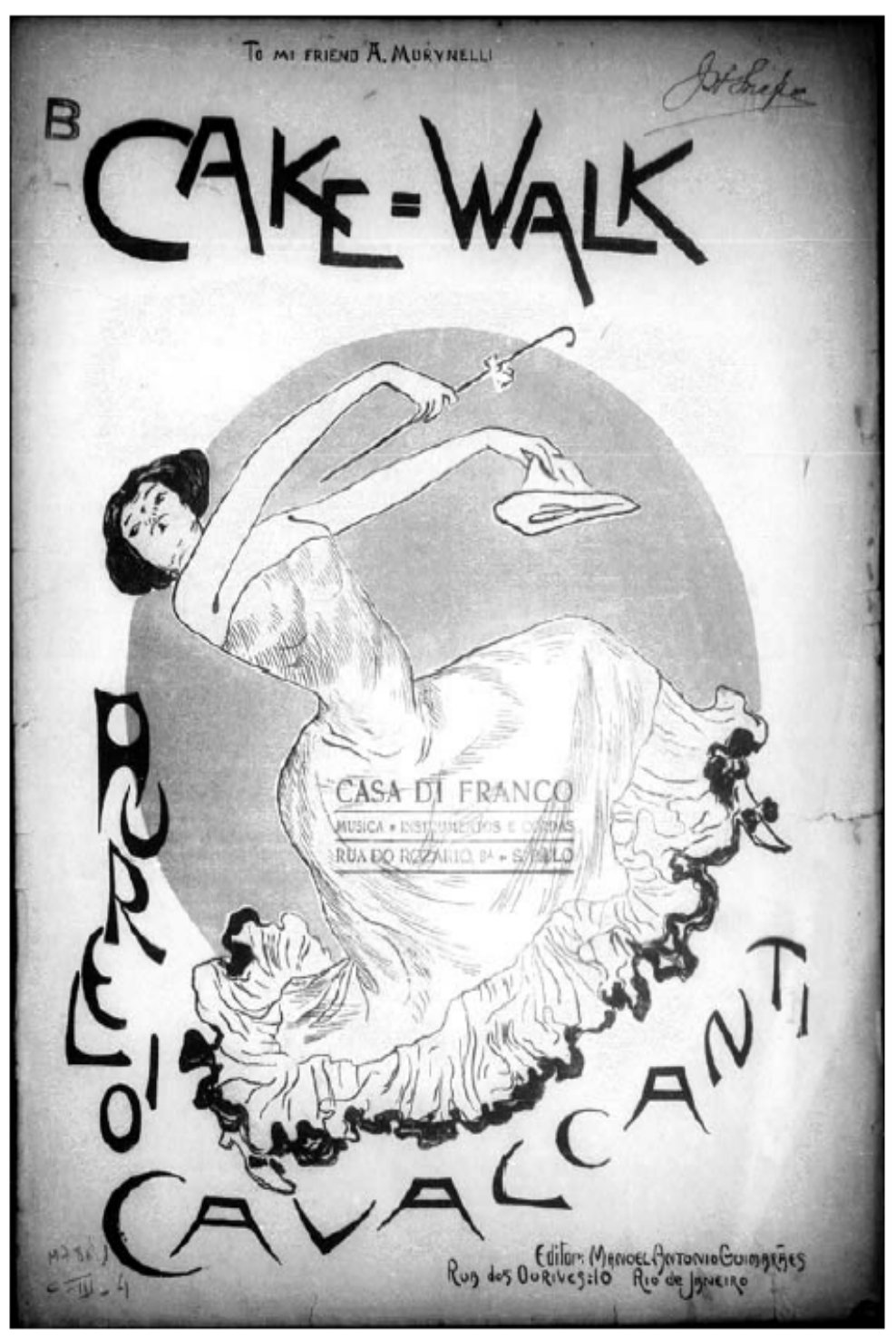

Ex. 11 - Capa de "Cake-walk", de Cavalcanti. Biblioteca Nacional do Rio de Janeiro, Divisão de Música e Arquivo Sonoro. 

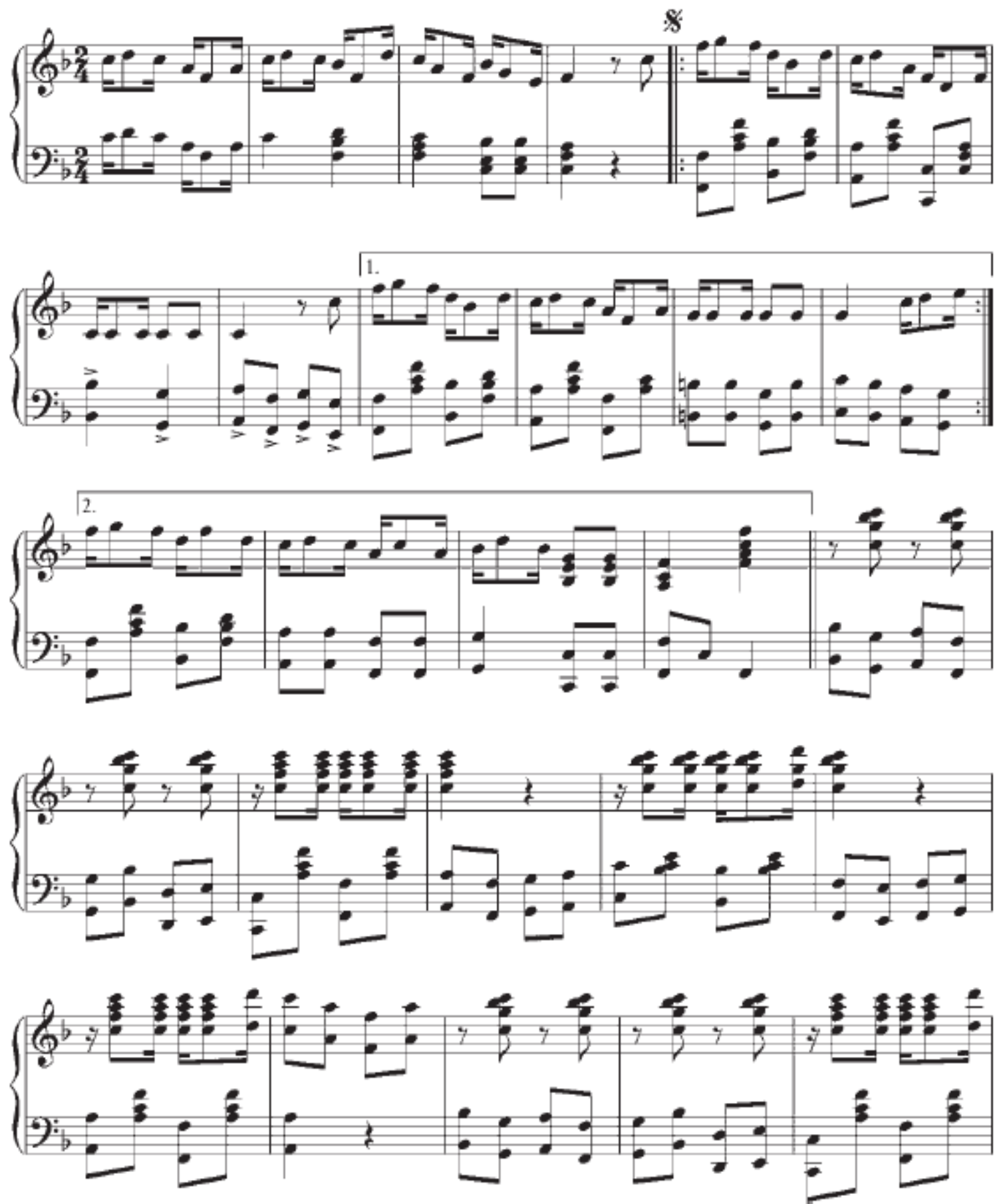

Ex. 12 - Aurélio Cavalcanti, "Cake-Walk" (c. 1903) (Rio de Janeiro: Editor Manoel Antonio Guimarães). Biblioteca Nacional do Rio de Janeiro, Divisão de Música e Arquivo Sonoro.

Enquanto o apelo do cakewalk e do ragtime numa cidade como o Rio de Janeiro lança luz sobre uma cultura cosmopolita compartilhada no começo do século $X X$, ele também aponta para um cosmopolitismo à maneira européia numa cidade que tinha sido dominada pelas tradições musicais herdadas da África desde os 
tempos coloniais. Se na canção de Milano, “Ti-fá”, pode-se achar uma conexão entre orientalismo e as discussões locais sobre política racial, a ideia da imigração chinesa era apenas um tópico temporário que logo perdeu sua força. Ele foi ofuscado por uma discussão muito maior sobre a nacionalidade brasileira focada especificamente no elemento africano, um elemento incontestavelmente presente e fortemente conectado com todas as facetas da vida brasileira. Bastante consciente das teorias europeias contemporâneas sobre raça, a intelligentsia local flertava com a ideia do "branqueamento" da população brasileira, através do aumento de subsídios para a imigração de europeus, evitando assim a suposta "degeneração" da cultura local, que era percebida como resultado do seu entrelaçamento com a africana. Dentro deste contexto, a propagação dos africanismos musicais como modernos e cosmopolitas era particularmente significativa no Rio de Janeiro, seja como compromisso quanto como fuga da discussão em curso sobre o papel da raça negra na construção da nacionalidade brasileira. Compreendidas como danças excêntricas dos negros dos Estados Unidos, o cakewalk e o ragtime viraram uma moda excêntrica na paisagem sonora urbana do Rio de Janeiro, nas comédias teatrais, nos musicais de revista e durante a época do Carnaval, quando eles dividiam o espaço não somente com valsas, polcas e marchas, mas também com a dança local do maxixe - uma variante da polca europeia e da marcha, conspicuamente ornamentada com síncopes tanto na linha melódica quanto no acompanhamento. No carnaval de 1909, por exemplo, Paschoal Segreto ofereceu em seu music hall um vivo "baile yankee com o delicioso cakewalk e não menos delicioso maxixe" (JORNAL..., 1909).

A inclusão do maxixe e do cakewalk era mais uma conjunção entre cosmopolitanismo e localidade marcada pelo exotismo, pois o maxixe também já tinha sido apresentado em Paris e se tornado parte do circuito internacional de intercâmbios musicais. Ao situar o maxixe duplamente como cosmopolita e exótico, a dança local poderia ser celebrada no Rio de Janeiro como parte da cultura local urbana $^{34}$. Como Whiting (1999, p. 300) aponta, "uma moda tem mil chances de se propagar localmente se ela vem de fora". O maxixe nesse contexto poderia perder seu potencial de autoexotismo e em vez disso se transformar em uma ferramenta

\footnotetext{
34 Veja minha discussão sobre o maxixe nesse contexto em MAGALDI, 2008.

MAGALDI, Cristina. Cosmopolitismo e world music no Rio de Janeiro na passagem para o século XX. Música Popular em Revista, Campinas, ano 1, v. 2, p. 42-85, jan.-jun. 2013.
} 
conveniente para a política local de representação racial. Micol Seigel (2005, p. 98) ofereceu uma convincente análise do aparecimento e desaparecimento do maxixe nos Estados Unidos, focando na relação da dança com outros intercâmbios culturais da diáspora africana na segunda década do século XX. A história destas trocas do ponto de vista do mercado musical florescente no Rio de Janeiro oferece exemplos similares, mas também pode fornecer outros pontos de vista para interpretações dessas já complexas interações transnacionais. Ela nos mostra não só as expressões musicais da diáspora africana como transnacionais, mas também mostra a sua realocação primeiramente de "transnacional" para "cosmopolita" e então, finalmente, para "local".

Se de um lado os africanismos musicais no cakewalk e no ragtime disfarçados como o Outro exótico serviam como uma forte ferramenta de marketing para as danças da moda estrangeiras, por outro lado o cakewalk e as danças e canções do ragtime eram particularmente úteis para validar a produção do maxixe por destacar os africanismos locais como sendo modernos e desejáveis por todos. Visto primeiramente como mais um elemento no vasto leque de possibilidades ofertadas pela circulação internacional da música e pelo difundido cosmopolitismo cultural, as canções e danças populares saturadas com síncopes adquiriram vida própria na capital brasileira. Fazendo parte de um discurso internacional de expressões africanas e afro-americanas que tinham emergido como representações do Outro dentro dos "limites de uma bem definida e rentável convenção de entretenimento de massa" (HICK, 2003, p. 98) elaborados por europeus brancos, elas se transformaram em conspicuamente celebrados significantes da música do Rio de Janeiro significantes que efetivamente e convenientemente diluíram conceitos de raça, cosmopolitanismo e singularidades locais num discurso único ${ }^{35}$. Na década de 1930, durante o auge de uma ditadura e inseridos em discursos de ideologias nacionalistas no Brasil, a síncope nas canções e danças populares não era mais celebrada como africanismos exóticos ou representantes do Outro, mas como símbolo de identidade local. Celebradas desesperadamente por musicólogos brasileiros e estrangeiros como

\footnotetext{
35 Hick (2003, p. 83) nota a indefinição das discussões que relacionam exotismo, raça e classe social na Inglaterra do final do século XIX.

MAGALDI, Cristina. Cosmopolitismo e world music no Rio de Janeiro na passagem para o século XX. Música Popular em Revista, Campinas, ano 1, v. 2, p. 42-85, jan.-jun. 2013.
} 
uma validação estética da produção musical local, as sincopações e outros africanismos, por fim, prenderam as expressões musicais dos afro-brasileiros numa caixa essencialista, marcada pela raça e diferença, da qual não havia escapatória pois se transformou, então, no símbolo máximo que veio moldar não somente o imaginário da música popular afro-brasileira, mas também da música brasileira como um todo, e, por fim, da brasilidade - um ícone inquestionável, do qual a autenticidade era inegável e onde a sua história não teria papel algum. Desta maneira, a música popular brasileira ficou historicamente inseparável das expressões musicais afro-brasileiras, criando um mito que continua até os dias atuais ${ }^{36}$.

Ainda assim, devemos nos perguntar como uma sociedade governada por uma elite branca cujo ideal de raça foi modelado nas teorias europeias e que investiu no "branqueamento" da população como uma solução que privilegiava a si própria nas então oportunas discussões sobre identidade e representação, poderia ver na música negra um potencial para construções locais da identidade nacional; ou seja, como poderiam os encarregados do "branqueamento" da população serem a favor do "enegrecimento" da música com o potencial para representar a identidade nacional? Esse paradoxo não deve ser considerado como um inerente mistério brasileiro, nem pode ser simplificado ou justificado pelos encontros amigáveis entre brancos e negros na boemia do Rio de Janeiro. Além da celebração internacional dos africanismos como modernos e atraentes, a produção da música popular na capital brasileira era dominada por um grande número de negros, que buscavam e encontravam trabalho na emergente indústria musical no Rio de Janeiro. Na capital do Brasil, eles se tornaram os pioneiros da produção e performance das novas músicas cosmopolitas, nacionais e estrangeiras, assim como aconteceu na Broadway no final do século XIX. Eles compreenderam bem e fizeram uso do exótico, dos orientalismos, africanismos e europeísmos, enquanto se posicionavam como verdadeiros cosmopolitas. Como Seigel (2009) nota em relação às performances afroamericanas, a produção e performance musicais afro-brasileiras dentro deste ambiente transnacionais e cosmopolitas de muitos exotismos não pode ser compreendida no interior de um esquema racial bem definido de brancos e negros.

\footnotetext{
36 Para um estudo recente sobre o papel dos músicos negros na música popular brasileira, ver DAVIS, 2009. MAGALDI, Cristina. Cosmopolitismo e world music no Rio de Janeiro na passagem para o século XX. Música Popular em Revista, Campinas, ano 1, v. 2, p. 42-85, jan.-jun. 2013.
} 
Na verdade, elas operaram dentro de esquemas múltiplos de competitividade racial, que trabalharam simultaneamente ${ }^{37}$.

Assim como Aurélio Cavalcanti, que era descrito por Luiz Edmundo como mulato, os negros (e mulatos) eram compositores e intérpretes de sucesso nos music halls, cafés-concertos e chopes-berrantes. Depois de uma chanson francesa, uma canção japonesa e uma dança alemã, como lembra Edmundo, eles poderiam satisfazer o público com polcas e valsas, e também com outras músicas cosmopolitas incluindo cakewalks, ragtimes, habaneras, tangos, maxixes, etc. Como verdadeiros cosmopolitas numa sociedade branca dominada pela cultura europeia, os compositores e performers negros e mulatos tinham que navegar em um complexo aparelho de dinâmicas sociais que era marcado pelas políticas de representação racial - como nos Estados Unidos, como diz Seigel (2009), “eles navegavam nas correntezas do colonialismo interno". Edmundo louvava as performances dos negros nos music halls do Rio de Janeiro pelas "suas cadências sincopadas do batuque africano" que eles somavam a todas as músicas, uma qualidade que os mostrava como "bárbaros". E continua: "era tanto que ninguém poderia aceitar outro tipo de intérprete durante o Carnaval" (EDMUNDO, 1987, p. 179). A raça negra era então crucial para se adicionar a "autenticidade africana" local nas produções e performances cosmopolitas no Rio de Janeiro - uma autenticidade que poderia ser apresentada e representada como paródia nos desfiles carnavalescos. No entanto, a participação dos negros na produção musical daquele período também era conveniente por outra razão: enquanto os negros obtinham sucesso como compositores e intérpretes cosmopolitas, eles deixavam invisível a conspícua presença das tradições africanas na capital brasileira. Suas contribuições para a cena da música popular, com uma gama de inovações musicais e interpretativas, proveram uma conveniente válvula de escape para os sons tradicionais dos batuques que continuavam a ser proibidos pela lei naquela cidade.

Esse cenário inicial da música popular no Rio de Janeiro assim apresenta uma dinâmica complexa de identidades, representações e significados que eram dependentes

\footnotetext{
$37 \mathrm{O}$ artigo de Seigel, que se encontra on-line, é um trecho do seu futuro livro Uneven Encounters: Making Race and Nation in Brazil and the United States (Durham, NC: Duke University Press, a ser publicado). 
tanto num circuito internacional de circulação musical como dentro de um contexto local marcado pelas políticas raciais da época. Enquanto essas relações complexas revelam uma história cuja magnitude vai além do escopo deste artigo, esses exemplos ligando a música popular europeia e norte-americana com a produção da música local oferecem uma maneira de ver a produção nacional como dependente de representações prévias que eram já contextualizadas como exotismos da moda. Desta forma, o processo pelo qual a música popular foi usada posteriormente, no século XX, para criar símbolos de brasilidade respaldando-se na tradição negra no Brasil, estava longe de ser intrínseco, natural, local. Enfim, era um processo construído por histórias compartilhadas e por intercâmbios culturais transnacionais. Esses exemplos permitem um exame da produção musical local no Rio de Janeiro que não esteja ligada intrinsecamente a uma identidade única local, e que, em lugar disso, pode ser compreendida como parte de uma cultura cosmopolita mais ampla, compartilhada por todos que viviam em cidades dos dois lados do Atlântico. $\mathrm{Na}$ indústria musical emergente no Rio de Janeiro, a música popular produzida localmente no início do século XX simplesmente adicionava um novo contexto local a um conjunto já familiar e incontestável de contextos culturais cosmopolitas.

\section{Referências}

AGAWU, Kofi. Representing African music: Postcolonial Notes, Queries, Position. New York and London Routledge, 2003.

ALMANDOZ, Arturo. Planning the Latin America's Capital cities, 1850-1950. London e New York: Routledge, 2002.

APPADURAI, Arjun. Modernity at Large, Cultural Dimensions of Globalization. Minneapolis: University of Minnesota Press, 1996.

BENCHIMOL, Jaime Larry. Pereira Passos: um Haussman tropical: a renovação urbana no Rio de Janeiro no início do século XX. Rio de Janeiro: Prefeitura do Rio de Janeiro, 1992.

BILAC, Olavo. Moléstias da época. Gazeta de Notícias, 3 nov. 1907.

BISPO, Alexandre. Luso-Brasileirismo, ítalo-brasileiros e mecanismos performativos: representações teatrais e revistas, Nicolino Milano. Brasil-Europa: correspondência euro-brasileira, v. 107, 2007. Disponível em: <http://www.revista.brasileuropa.eu/107/Nicolino-Milano.htm>. Acesso em: 29 abr. 2013.

MAGALDI, Cristina. Cosmopolitismo e world music no Rio de Janeiro na passagem para o século XX. Música Popular em Revista, Campinas, ano 1, v. 2, p. 42-85, jan.-jun. 2013. 
BLAKE, Jody. Taking the Cake: The First steps of Primitivism in Modernist Art. Le tumulte noir: Modernist Art and Popular Entertainment in Jazz-Age Paris, 1900-1930. University Park, The Pennsylvania State University Press, 1999.

BOHLMAN, Philip. World Music at the End of History. Ethnomusicology, v.46, no. 1, outono 2002.

BRECKENRIDGE, Carol A. et al (ed). Cosmopolitanism. Durham, NC: Duke University Press, 2002.

CHANDA, Nayan. Boud Together: How Traders, Preachers, Adventures and Warriors Shaped Globalization. New Haven, CT: Yale University Press, 2007.

CHEAH, Pheng; ROBBINS, Bruce (ed). Cosmopolitics: Thinking and Feeling Beyond the Nation. Minneapolis: University of Minnesota Press, 1998.

CONDE, Marite. Film and the Crônicas: Documenting the New Urban Spaces in Turn of the Century Rio de Janeiro. Luso-Brazilian Review, v.42, n.2, 2005.

CORONA, Ignacio; MADRID, Alejandro L. Postnational Musical Identities: cultural production, distribution, and consumption in a globalized scenario. Lanham, MD: Lexington Books, 2008.

DAVIS, Darién. White Face, Black Mask: Africaneity and the Early Social History of Popular Music in Brazil. East Leasing: Michigan State University Press, 2009.

EDMUNDO, Luiz. O Rio de Janeiro do meu tempo. Rio de Janeiro: Xenon Editora, 1987 [1938].

ERLMANN, Veit. The Aesthetics of the Global Imagination: Reflections on World's Music in the 1990s. Public Culture, no 8, 1996.

FELD, Steven. A Sweet Lullaby for World Music. Public Culture, v.12, n.1, outono 2000.

FOJAS, Camilla. Cosmopolitanism in the Americas. West Lafayette, IN: Purdue University Press, 2005.

GONZÁLEZ, Juan Pablo; ROLLE, Claudio. Historia social de la música popular en Chile, 1890-1950. Santiago, Chile: Ediciones Universidad Católica de Chile, 2005.

HICK, William L. Social Discourse in the Savoy Theatre's Productions of The Nautch Girl (1891) and Utopia Limited (1893): Exoticism and Victorian Self-Reflection. Dissertação (Mestrado), University of North Texas, 2003. Disponível em: 
<http://www.library.unt.edu/theses/20032/hicks_william/thesis.pdf>. Acesso em: 01 mai. 2009.

LESSER, Jeffrey. Negotiating National Identity: Immigrants, Minorities, and the Struggle for Ethnicity in Brazil. Durham, NC: Duke University Press, 1999.

LIMA, Evelyn Furquim Werneck. Arquitetura do espetáculo: teatros e cinemas na formação da Praça Tiradentes e da Cinelândia. Rio de Janeiro: Editora UFRJ, 2000.

LOSS, Jacqueline. Cosmopolitanisms and Latin America: against the destiny of place. New York: Palgrave Macmillan, 2005.

MAGALDI, Cristina. Adopting Imports: New Images and Alliance in Brazilian Popular Music of the 1990s. Popular Music, Cambridge, v.18, n.3, p.309-29, out. 1999.

Music in Imperial Rio de Janeiro: European culture in a tropical milieu. Lanham, MD: Scarecrow Press, 2004.

Before and After Samba: Modernity, Cosmopolitan and Popular Music in Rio de Janeiro at the Beginning and End of the Twentieth Century. In: CORONA, Ignacio; MADRID, Alejandro L. Postnational Musical Identities: Cultural Production, Distribution, and Consumption in a Globalized Scenario. Lanham, MD: Lexington Books, 2008, p. 173-84.

MCKINLEY, Ann. Debussy and American Minstrelsy. The Black Perspective in Music, Autumn, 1986.

MEADE, Teresa A. Civilizing Rio: Reforms and Resistance in a Brazilian City, 18891930. University Park: The Pennsylvania State University Press, 1997.

MIDDLETON, Richard; MANUEL, Peter. Popular music. Grove Music Online, Oxford Music Online. Oxford: s.d. Disponível em: <http://www.oxfordmusiconline.com/subscriber/article/grove/music/43179pg2>. Acesso em: 01 mai. 2009.

NEEDELL, Jeffrey D. A Tropical Belle Époque. Cambridge: Cambridge University Press, 1987.

Rio de Janeiro and Buenos Aires Public Space and Public Consciousness in Fin-de-siècle Latin America. Comparative Studies in Society and History, v.37, n.3, jul. 1995.

OLIVEIRA, Cláudia. A representação da grande Avenida e o sublime dos "melhoramentos urbanos" nas ilustradas Fon-Fon! e Para Todos. Escritos: Revista da Casa Rui Barbosa, n. 1, 2007. 
ROSEN, Jody. How Pop Sounded Before it Poped. New York Times, New York, 19 mar. 2006.

SAID, Edward. Orientalism. New York: Vintage Books, 1994 [1978].

SAN Toy. British Musical Theatre, s.d. Disponível em: <http://math.boisestate.edu/GaS/british/santoy/index.html>. Acesso em: 01 ma. 2009.

SCOTT, Derek B. Orientalism and Musical Style. Musical Quaterly, v. 88, n. 2, 1998.

Sounds of the metropolis: the nineteenth-century popular music revolution in London, New York, Paris and Vienna. New York: Oxford University Press, 2008.

SEIGEL, Micol. The disappearing dance: maxixe's imperial erasure. Black Music Research Journal, v.25, primavera 2005.

Nation Drag: Uses of the Exotic. Journal of Transnacional American Studies, v. 1, n $\mathrm{n}^{\mathrm{O}} \quad$ I, 2009.2 Disponível em: <http:/ / repositories.cdlib.org/xgi/viwecontente.cgi?article=1078\&context=acgcc/jta s>. Acesso em: 03 mai. 2009.

WEHRS, C. Carlos J. O Rio antigo, pitoresco \& musical: memórias e diário. Rio de Janeiro: Carlos Wehrs, 1980.

WHITING, Steven Moore. Satie the Bohemian: from cabaret to concert hall. Oxford: Oxford University Press, 1999.

\section{Periódicos}

CORREIO DA MANHÃ. Rio de Janeiro, 3 jan. 1903.

JORNAL DO COMMERCIO. Rio de Janeiro, 25 fev. 1901.

. Rio de Janeiro, 19 fev. 1909.

. Rio de Janeiro, 5 mai. 1910.

. Rio de Janeiro, 19 mai. 1910.

Rio de Janeiro, 1 set. 1910. 